\title{
A systematic review of the impact of Person-Centred Care interventions on the behaviour of staff working in dementia care
}

DOI:

10.1111/jan.14251

\section{Document Version}

Accepted author manuscript

Link to publication record in Manchester Research Explorer

Citation for published version (APA):

Blake, D., Berry, K., \& Brown, L. J. E. (2020). A systematic review of the impact of Person-Centred Care interventions on the behaviour of staff working in dementia care. Journal of Advanced Nursing. https://doi.org/10.1111/jan.14251

\section{Published in:}

Journal of Advanced Nursing

\section{Citing this paper}

Please note that where the full-text provided on Manchester Research Explorer is the Author Accepted Manuscript or Proof version this may differ from the final Published version. If citing, it is advised that you check and use the publisher's definitive version.

\section{General rights}

Copyright and moral rights for the publications made accessible in the Research Explorer are retained by the authors and/or other copyright owners and it is a condition of accessing publications that users recognise and abide by the legal requirements associated with these rights.

\section{Takedown policy}

If you believe that this document breaches copyright please refer to the University of Manchester's Takedown Procedures [http://man.ac.uk/04Y6Bo] or contact uml.scholarlycommunications@manchester.ac.uk providing relevant details, so we can investigate your claim.

\section{OPEN ACCESS}


A systematic review of the impact of Person-Centred Care interventions on the behaviour of staff working in dementia care

Daniel Blake, Katherine Berry, \& Laura J. E. Brown

Division of Psychology and Mental Health, School of Health Sciences, University of Manchester.

This is a pre-copyedited, author-produced PDF of an article accepted for publication in the Journal of Advanced Nursing following peer review. The final published version of the article (Blake et al., 2019) can be found on the journal's website:

https://onlinelibrary.wiley.com/journal/13652648

Corresponding author: Dr Laura Brown. Division of Psychology and Mental Health, School of Health Sciences, The University of Manchester, Room 2.32, Second Floor, Zochonis Building Brunswick Street, Manchester M13 9PL. Unitied Kingdom.

Tel: +44 (0)1612752563

Email: laura.brown@manchester.ac.uk

Conflict of interest statement:

"No conflict of interest has been declared by the author(s)."

Funding statement:

"This research received no specific grant from any funding agency in the public, commercial, or not-for-profit sectors." 


\section{ABSTRACT}

Aim: To examine the content, focus, and effectiveness of person-centred care (PCC) interventions aimed at increasing staff PCC behaviour in health and social care settings for people with dementia.

Design: Systematic search and narrative synthesis of quantitative data.

Data sources: PsychINFO, Medline, EMBASE, Web of knowledge, CINAHL, ASSIA and BNI were searched from inception to $5^{\text {th }}$ November 2016.

Review methods: All records retrieved were screened using predetermined eligibility criteria. Quality assessment was performed with the Effective Public Health Practice Project tool (EPHPP).

Results: A total of 4,367 records were screened, and 33 studies examining the impact of PCC interventions were included. Eight different categories of PCC intervention were identified, with seven of these having at least some evidence to support their effectiveness in increasing staff PCC behaviour.

Conclusion: The range of interventions and outcome measures identified in this review highlight different ways in which PCC behaviour can be demonstrated by staff, and the range of interventions that can be used to enhance PCC staff behaviour. Future, more rigorously controlled research comparing the relative effectiveness of these interventions, will support nursing facilities and staff to choose appropriate interventions to support them in enhancing PCC.

Impact: This study addressed the health priority of increasing PCC for people with dementia. It found preliminary evidence that seven of the eight intervention types identified are effective at increasing staff PCC behaviour in health and social care settings for people with dementia.

Keywords: Person centred care, interventions, dementia, staff behaviour, literature review, systematic review. 
INTRODUCTION

Dementia care is a global priority, with $\mathbf{4 7 . 5}$ million people living with a form of dementia worldwide (World Health Organization, 2016). An increase in people living with long-term conditions, such as dementia, means that pressure on services is rising (Royal College of Nursing, 2010). For instance, roughly a quarter of UK hospital beds are occupied by a person with dementia (Department of Health, 2013), and people with dementia are more likely to be discharged into residential care than return to their family home (Alzheimer's Society, 2014). However, only $41 \%$ of family members think that their relative has a good quality of life in residential care (Alzheimer's Society, 2013), suggesting that there is an important need for care provision to be improved. In addition, the Royal College of Psychiatrists (2018) highlight the need to question whether care is provided in a personal manner throughout the National Health Service.

\section{Background}

Person Centred Care (PCC) is a key standard in the National Service Framework for Older people (Department of Health, 2001), and is highlighted in a number of national guidelines for people with dementia (e.g. NICE, 2006; Department of Health, 2009). Edvardsson, Winbald, and Sandman (2008) drew on Kitwood (1997) to conceptualise PCC as behaviour that acknowledges the subjective experience of the individual; involves sharing decisions and offering choices; uses an individual's life history to guide their care; and focuses on the person's retained skills and abilities. They also describe PCC as involving interactions in which an authentic relationship is fostered that provides unconditional positive regard, and that benefits the overall wellbeing of the care recipient and their sense of self (Edvardsson, Winbald, \& Sandman, 2008). For instance, in a care home setting, helping someone to get washed and dressed can be done in a task-focused way by ensuring these routines are completed efficiently and the person is clean and comfortable. Alternatively, a PCC approach can be adopted, whereby the staff member considers what time the person usually likes to rise; offers a bath or a shower based on their preferences; and uses historical knowledge of the person to engage them in a comfortable level of conversation around valued topics. This definition is consistent with the 'VIPS' model of PCC, proposed by 
Brooker (2003), which refers to four main elements: Valuing the person with dementia and their carers (V); treating people with dementia as individuals (I); seeing the world from the perspective of the person with dementia $(\mathrm{P})$; and providing a positive social environment which focuses on enhancing well-being (S).

Personhood is also central to the notion of PCC, and is defined as the sense of wellbeing generated for a person when other people recognise and respect their preferences and needs (Kitwood, 1997). Positive person work (e.g. providing comfort through non-verbal channels; consulting the person with dementia to obtain their wishes; supporting them to continue with valued activities) increases personhood, whereas the term 'malignant social psychology' is used to refer to behaviour that reduces the personhood of people with dementia by, for example, disempowering, intimidating, or objectifying them (Kitwood, 1997, 46).

PCC can be measured in a diverse range of ways. Indeed De Silva (2014) report that approximately 200 tools have been designed for this purpose. Whilst PCC can be measured directly, through observations or self-reports of behaviour, Bird et al., (2016) note that PCC is often measured indirectly, e.g. through observable changes in the person with dementia, such as whether their mood improves or levels of challenging behaviour decrease.

Kitwood's approach to PCC has been important in the development of a range of nonpharmacological interventions for people with dementia that move away from the traditional medical approach (Barbosa, Sousa, Nolan, \& Figueiredo, 2015). Such interventions, including validation therapy and reality orientation, utilise stimulation, emotion, behaviour, and cognitive-orientated approaches (Barbosa et al., 2015), and are effective at improving clinical outcomes for people with dementia (Livingston et al., 2014).

Previous systematic reviews have also provided preliminary evidence for the effectiveness of selected PCC interventions on staff behaviour in dementia care settings. However, these reviews have been limited in terms of the intervention type or outcomes considered. For example, Fossey et al., (2014) found that manualized PCC interventions significantly reduced anti-psychotic use by staff, but they did not assess other forms of staff behaviour. Low et al., 
(2015) found evidence for the effectiveness of staff interventions that targeted a broader range of staff care behaviours, including those related to physical health, falls, and nutrition. However, this review was not specifically focused on PCC interventions, and did not include terms relevant to PCC in the search strategy. Thus, whilst some of the interventions identified did target PCC, it is likely that many PCC intervention studies were missed. Similarly, whilst Bird et al., (2016) found evidence for the effectiveness of interventions that aim to change staff caring behaviour in residential dementia care, their review did not specifically focus on PCC, and was limited to people living in long-term residential care. The current review therefore sought to add to the literature by providing a comprehensive overview of PCC interventions that target staff PCC behaviour in dementia settings, and evaluating the effectiveness of these interventions at changing a wide range of staff PCC behaviours.

The Review

Aims

The aims of this review were to: 1 ) examine the content and focus of PCC interventions that have been used in dementia care; and 2) assess the effectiveness of these PCC interventions in increasing staff PCC behaviour.

\section{METHOD}

A protocol for this systematic review was registered on the International prospective register of systematic reviews 'Prospero' (https://www.crd.york.ac.uk/PROSPERO/) before searches were conducted (Identification number:_CRD42016048138)

Inclusion and exclusion criteria

In order to be eligible for the review, papers had to have been published in a peer-reviewed journal, written in English, and meet the following inclusion criteria related to the five areas of: I) study design, II) intervention delivered, III) participants, IV) clinical context, and V) outcome measures used. 


\section{l) Study design}

Preliminary scoping searches of the literature suggested that only a limited amount of controlled studies had been conducted in this area. An inclusive approach to study design was therefore taken, such that any controlled or non-controlled studies, in which both pre and post measurements of staff behaviour were taken, were included in the review. Case study designs were excluded.

\section{II) Intervention}

The intervention could be any psychosocial intervention that aimed to improve the PCC behaviour of professional caregivers. Interventions were included if they stated that they were person-centred, or aimed to make care more person-centred (Barbosa et al., 2015), and/or if they were judged by the review team to capture key features of PCC, as described by Edvardsson et al., (2008: Figure 1). In order to ensure that no potentially relevant interventions were missed, a liberal approach was taken when making judgements about whether or not a particular intervention could be considered to be person-centred.

- Acknowledging the individual, and fostering personhood, through authentic relationships and positive person work

- Viewing situations from the individual's viewpoint

- Sharing decision making and offering choices

- Using life history to guide care

- Focusing on skills and abilities

- Unconditional positive regard

- Prioritising well-being

- Skilled companionship

- Personalized environments

Figure 1: Aspects of PCC according to Edvardsson et al. (2008). 


\section{III) Participants}

Intervention participants had to be people who provided care to people with dementia in a professional capacity, regardless of whether this was in a paid or unpaid role. Interventions targeting the behaviours of family members or friends providing informal care to someone with dementia were not included. Interventions were also required to have more than two participants.

\section{IV) Clinical context}

The intervention had to focus on changing behavior within a care environment designed for people with dementia. This could include any formal health or social care setting where staff members are available to provide support to people with dementia, including inpatient wards, residential homes, and assisted living facilities. For the study to be considered eligible, at least some people with dementia had to be present in the clinical environment where the intervention had been delivered. This was determined by examining whether or not people with dementia were listed as participants in the study, or from the description of the setting.

\section{V) Outcome measures}

Studies that collected quantitative outcome measures of one or more aspect of staff PCC behaviour were considered eligible for the review.

\section{Search strategy}

A search was conducted across PsycINFO, Embase, Medline (Ovid), Web of Science, Cumulative Index to Nursing and Allied Health Literature (CINAHL), British Nursing Index (BNI) and Proquest Applied Social Sciences Indexes and Abstracts (ASSIA). Each database was searched from its inception to $5^{\text {th }}$ November 2016. Four strings of terms connected by the Boolean operator 'AND' were used to capture the concepts of: PCC; intervention; 
participants; and the clinical population. Terms for the concept of PCC was drawn from key literature in the field, such as Kitwood (1997) and Edvardsson et al., (2008). The search strategy was developed for the Ovid platform (Supplementary Table 1), and then adapted to fit the parameters of the other platforms, as necessary. The searches were limited to peer reviewed journals written in English.

Search outcome

The search produced 6,591 results, which were exported into an endnote library, where 2,224 duplicate records were excluded. The titles and abstracts of the remaining 4,367 references were then screened for eligibility. In order to ensure that screening was reliable, a $10 \%$ subset of these (439 titles and abstracts) were independently screened by a second reviewer. The two reviewers frequently compared subsets of screening decisions until a high $(<95 \%)$ of inter-rater reliability had been achieved. The rest of the titles and abstracts were then reviewed by one reviewer. A total of 4,141 articles were excluded at title and abstract screening stage. Full texts of the remaining 226 full texts were subsequently accessed and assessed for eligibility by one reviewer, and discussed with one or more of the other authors where there was ambiguity about inclusion. This process led to 33 articles (describing 23 different interventions) that met the inclusion criteria being identified. See Figure 2 for a diagrammatic representation of the PRISMA search strategy (Moher, Liberati, Tetzlaff, and Altman, 2009). 


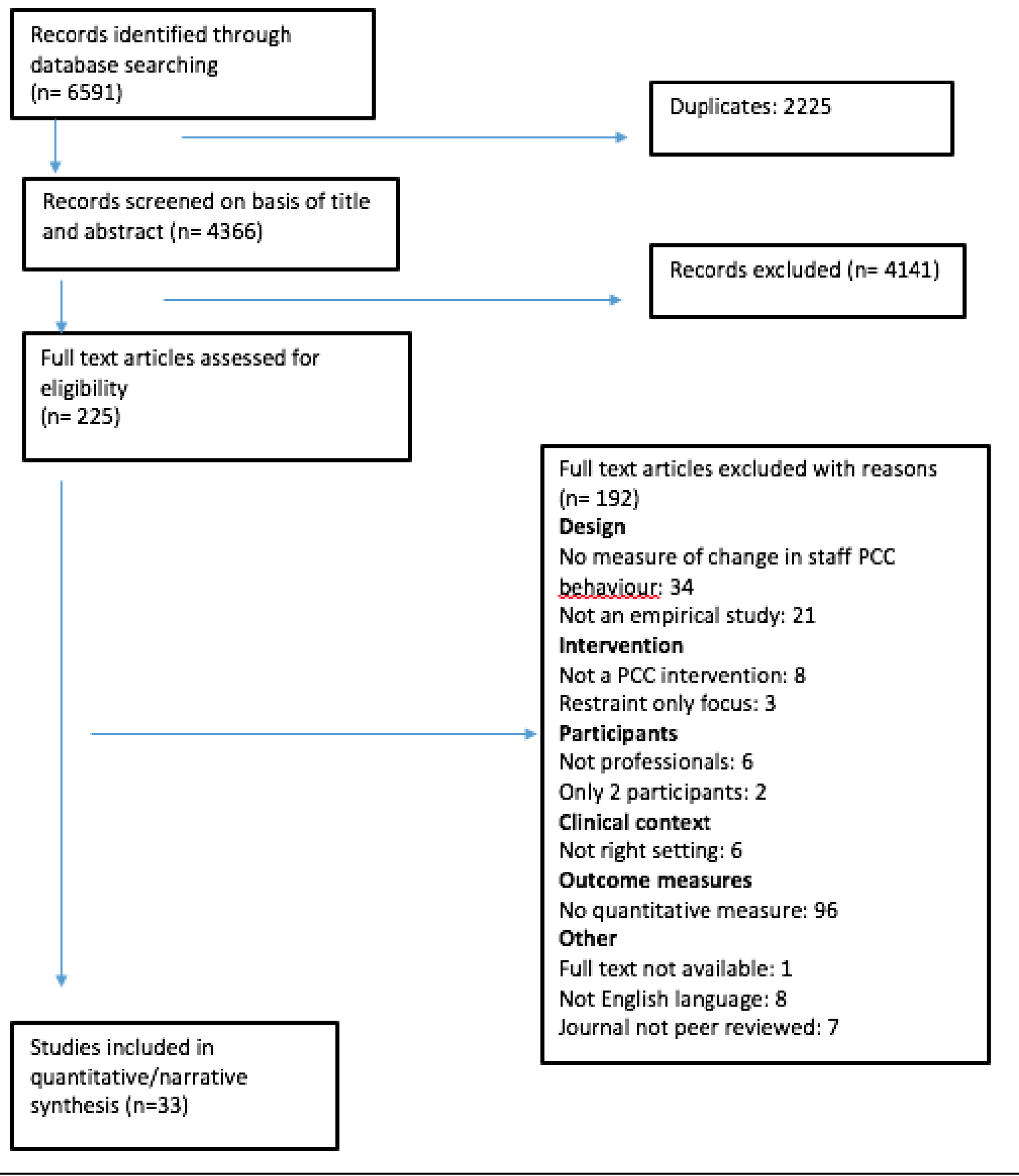

Figure 2. PRISMA diagram for search strategy.

Quality appraisal

The Effective Public Health Practice Project (EPHPP) 'Quality Assessment Tool for

Quantitative Studies' (Thomas, Ciliska, Dobbins, \& Micucci, 2004) was used to rate the 
quality of all studies included in the review. This tool enables reviewers to assign strong, moderate, or weak ratings to a study for the domains of: selection bias, design, confounders, blinding, data collection methods, and withdrawals and drop outs. In order to enable one group pre-test post-test designs to be assessed, the tool was adapted such that these studies would be rated 'weak' for control of confounders during quality assessment. An overall rating of strong, moderate, or weak was assigned according to the number of weak ratings received (Thomas, Ciliska, Dobbins, \& Micucci, 2004). Each study was independently assessed by the first author and a second reviewer. Any discrepancies were discussed, and resolved, through discussion with a third reviewer, when necessary.

Data abstraction

In order to ensure that consistent types of information were gathered about each study, the first author extracted data from all eligible studies using a standardized data extraction form. Cohen's D was calculated for all relevant variables. Where means, standard deviations, and sample sizes were not available to calculate an effect size, this information was requested from authors via e-mail. All contacted authors responded to the request for further information and provided data where it was available.

Synthesis

To address our first research aim, the interventions were categorised by the review team into different types of PCC intervention based on common features identified when reading intervention descriptions. To address the second aim, a narrative synthesis was performed, in which details of the quality ratings and proportion of significant findings were considered for all studies within each category, so that an overall judgement about effectiveness could be made. 


\section{RESULTS}

Characteristics of the studies and interventions

Summaries of the 33 studies, and the 23 interventions that they described, are presented in Table 1. The 23 interventions were carried out in the USA $(n=11)$, Canada $(n=2)$, Netherlands $(n=3)$, Portugal $(n=1)$, Sweden $(n=3)$, United Kingdom $(n=1)$, UK and Australia $(n=1)$ and Taiwan $(n=1)$. Sample sizes ranged from four to 171 staff members, although in seven studies the total number of staff involved was not reported. The interventions were carried out in nursing homes $(n=12)$, residential homes $(n=2)$, long term care $(n=2)$, hospital wards $(n=3)$, long term care with specialism in memory difficulties $(n=1)$, multiple settings, $(n=2)$, and nursing facilities $(n=1)$. All of the interventions were conducted with participants who provided care in a paid, rather than unpaid, capacity.

Overview of quality of studies

Eighteen of the 33 studies were classified as weak; 13 as moderate, and two as strong (Table 2 and Supplementary Table 2). It was not clear in any of the studies how the particular clinical setting was selected, which prevented strong ratings from being allocated in this domain. Reasons for weak ratings being given for selection bias were: non-probability sampling; staff volunteering to take part rather than being randomly selected; and a low percentage of participants agreeing to participate. Two studies received a weak rating for study design because they used an audit design that was not recognized as a rigorous method in the EPHPP tool.

Moderate ratings for blinding were assigned to 25 studies because it was not possible to determine if researchers were aware of which participants were in the intervention group. The eight studies given a weak rating were explicit about researchers or outcome assessors being aware of whether participants had received the intervention. Eighteen studies received a weak rating for confounders due to a lack of control groups or a failure to assess or control for baseline differences between groups. 
Data collection tools were rated as weak in 13 studies because no evidence about the validity of the tool was reported. Thirteen studies received a weak rating for the withdrawals and drop outs criterion because of either reporting a dropout rate of over $60 \%$, or because it was not possible to tell how many people dropped out.

Research aim 1: Content and focus of PCC interventions used in dementia care

The interventions were categorised into the following eight groups:

1. Staff communication training/memory book interventions $(n=10)$. These interventions involved providing people with dementia with memory books, and training staff how to use these in order to engage people with dementia in meaningful conversation. These interventions also involved training staff in person centred communication skills, and providing staff with feedback from observations of their interactions with people with dementia.

2. Supporting staff with emotional reactions $(n=2)$. The defining feature of these interventions was a focus on providing staff with strategies to manage the emotional impact of caring for someone with dementia. These strategies were broad and involved relaxation, exercise, information about dementia, and an increased provision of clinical supervision.

3. Dementia Care Mapping (DCM). DCM was implemented as part of an audit cycle across a number of studies, which enabled its use as an intervention. This involved staff being observed and provided with feedback about the person centred care observed; an action plan developed for increasing PCC; and the staff being observed again in order to measure change.

4. Interventions focussed on retaining abilities $(n=2)$. These interventions provided staff with structured training on how to focus on, and draw out, a person with dementia's strengths, skills, and abilities. Local 'champions' who worked alongside staff were used to support staff to implement a range of ability focused interventions including 
communication and relaxation strategies, and strategies that orient the person with dementia to the current task and provide them with tools to aid in its completion.

5. Sensory-focussed Interventions $(n=2)$. These involved staff being trained in sensory assessment and the implementation of sensory strategies. Staff were also trained in skills relating to empathy and non-verbal communication

6. Integrity promoting care $(n=1)$. This intervention aimed to promote a sense of integrity through building trust, autonomy, and maintaining identity for people with dementia. It involved providing staff with structured training about life stage theory; modifying environments to meet the needs of people with dementia; and supporting staff to change their approach to interaction. Staff training in these studies was based on Erikson's (1982) model of life stages, and involved discussions on how to promote integrity, as opposed to despair, in the context of old age and dementia.

7. Systemic interventions $(n=2)$. These aimed to influence the care provided over a whole facility. That is, they attempted to change staff practice across a number of sites and involved various layers of the organisation in planning, delivering, and monitoring of the PCC intervention.

8. Other interventions which did not fall into any of the aforementioned categories $(n=3)$. This included a PCC training course; a PCC bathing intervention; and training in integrity promoting care. 
Table 1 Summary of studies and interventions

\begin{tabular}{|c|c|c|c|c|}
\hline Author & Location & Participants & Clinical Context & Intervention \\
\hline \multicolumn{5}{|c|}{ Staff communication training/Memory book interventions } \\
\hline $\begin{array}{l}\text { Allen-Burge, } \\
\text { Burgio, } \\
\text { Bourgeois, } \\
\text { Sims, \& } \\
\text { Nunnikhoven, } \\
\text { (2001) }\end{array}$ & USA & $\begin{array}{l}12 \text { Nursing } \\
\text { assistants, \& } 3 \\
\text { licensed } \\
\text { practice } \\
\text { nurses (LPNs). }\end{array}$ & Nursing home & $\begin{array}{l}\text { Communication skills and memory book training } \\
\begin{array}{l}\text { - } \\
\text { Provision of memory books to people with } \\
\text { dementia. } \\
\text { - Staff training: memory books, communication } \\
\text { skills, understanding behaviour } \\
\text { - Behavioural supervision system: observations, } \\
\text { feedback, and self-monitoring for staff }\end{array}\end{array}$ \\
\hline Boscart, (2009) & Canada & $\begin{array}{l}24 \text { staff } \\
\text { members }\end{array}$ & Hospital ward & $\begin{array}{l}\text { Education program based on the Solution Focused } \\
\text { Brief Therapy approach (SFBT). } \\
\begin{array}{l}\text { - Feedback on video recorded interactions with? } \\
\text { - Information around SFBT communication } \\
\text { - Practice using communication skills. }\end{array}\end{array}$ \\
\hline $\begin{array}{l}\text { Bourgeois, } \\
\text { Dijkstra, Burgio, } \\
\text { \& Allen, (2003) }\end{array}$ & USA & $\begin{array}{l}126 \text { nursing } \\
\text { aides, } 23 \text { LPNS }\end{array}$ & $\begin{array}{l}7 \text { Long term } \\
\text { care facilities }\end{array}$ & $\begin{array}{l}\text { Communication skills training including memory books } \\
\text { and staff management } \\
\begin{array}{l}\text { - Provision of memory books } \\
\text { - Group and individual training. }\end{array}\end{array}$ \\
\hline
\end{tabular}


- Observations, feedback, and self-monitoring for NAs

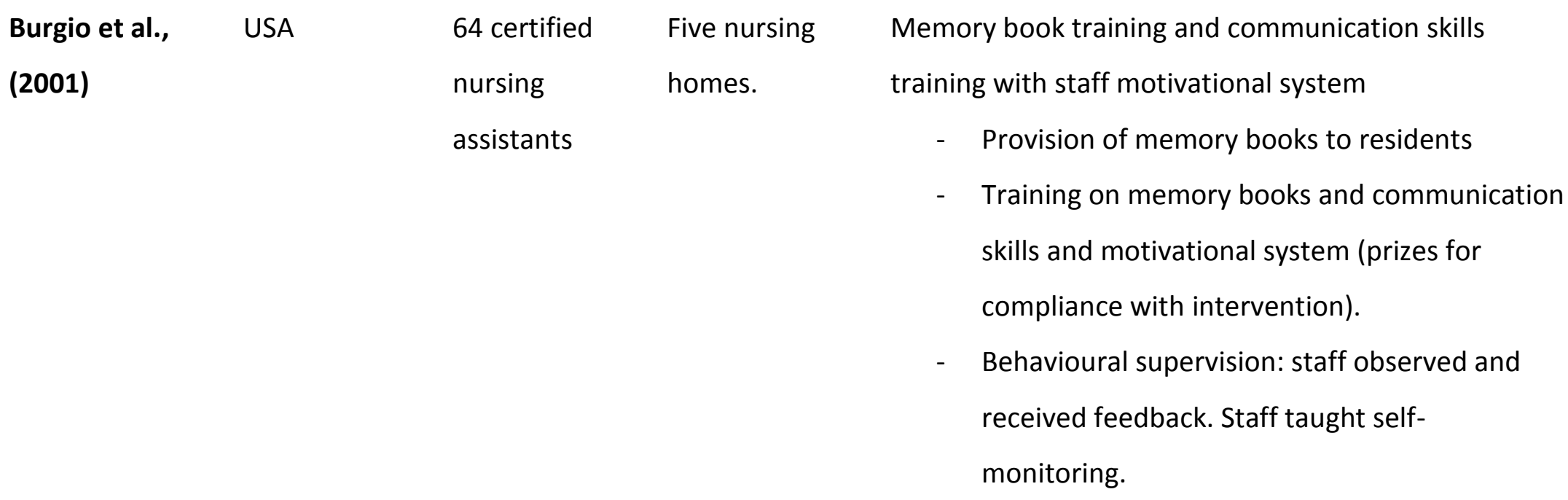

Burgio et al., USA 106 certified Two nursing Behaviour management skills training with formal staff (2002)

nursing homes

assistants

management (FSM)

- Training course element (5 hours over 3 days): communication skills, techniques for behaviour management

- One to one training: observation and feedback

- FSM: supervisors monitor skills and provide feedback. Training to all stakeholders to explain this system. Supervisors received extra 


\begin{tabular}{|c|c|c|c|c|}
\hline \multirow[b]{2}{*}{$\begin{array}{l}\text { Chao et al., } \\
\text { (2016) }\end{array}$} & \multirow[b]{2}{*}{ Taiwan } & \multirow[b]{2}{*}{107 nurses } & \multicolumn{2}{|r|}{ training. } \\
\hline & & & $\begin{array}{l}\text { Residents from } \\
\text { a variety of }\end{array}$ & $\begin{array}{l}\text { Advanced Innovative Evidence-based Computer } \\
\text { Education (AlICE) program ( } 4 \text { modules) }\end{array}$ \\
\hline & & & long term care & Face to face and internet elements \\
\hline & & & facilities & Peer supervision and evaluation process implemented. \\
\hline Dijkstra, & USA & 39 nursing & Residents with & Training in use of memory books and communication \\
\hline Bourgeois, & & assistants & dementia in & skills training \\
\hline Burgio, \& Allen, & & & seven nursing & - Training session \\
\hline (2002) & & & homes & $\begin{array}{l}\text { - Daily observation and training (feedback) in } \\
\text { effective communication skills. }\end{array}$ \\
\hline Hoerster, & USA & Four nursing & Nursing home & Memory books provided. Staff given instructions on \\
\hline Hickey, \& & & assistants & & how to interact with resident while looking at their \\
\hline Bourgeois, & & & & memory book. \\
\hline (2001) & & & & \\
\hline Passalacqua \& & USA & 26 Caregivers & Long term care & VIPS communication skills training \\
\hline Harwood, & & & institution with & - 4 workshops focusing on one part of the \\
\hline (2012) & & & specialism in & Brooker (2004) model of PCC: Valuing people, \\
\hline & & & memory & individualized care, personal perspectives, and \\
\hline & & & problems & social environment. \\
\hline Sprangers, & Netherlands & 24 nursing & Nursing home & Training program around communication styles for \\
\hline
\end{tabular}




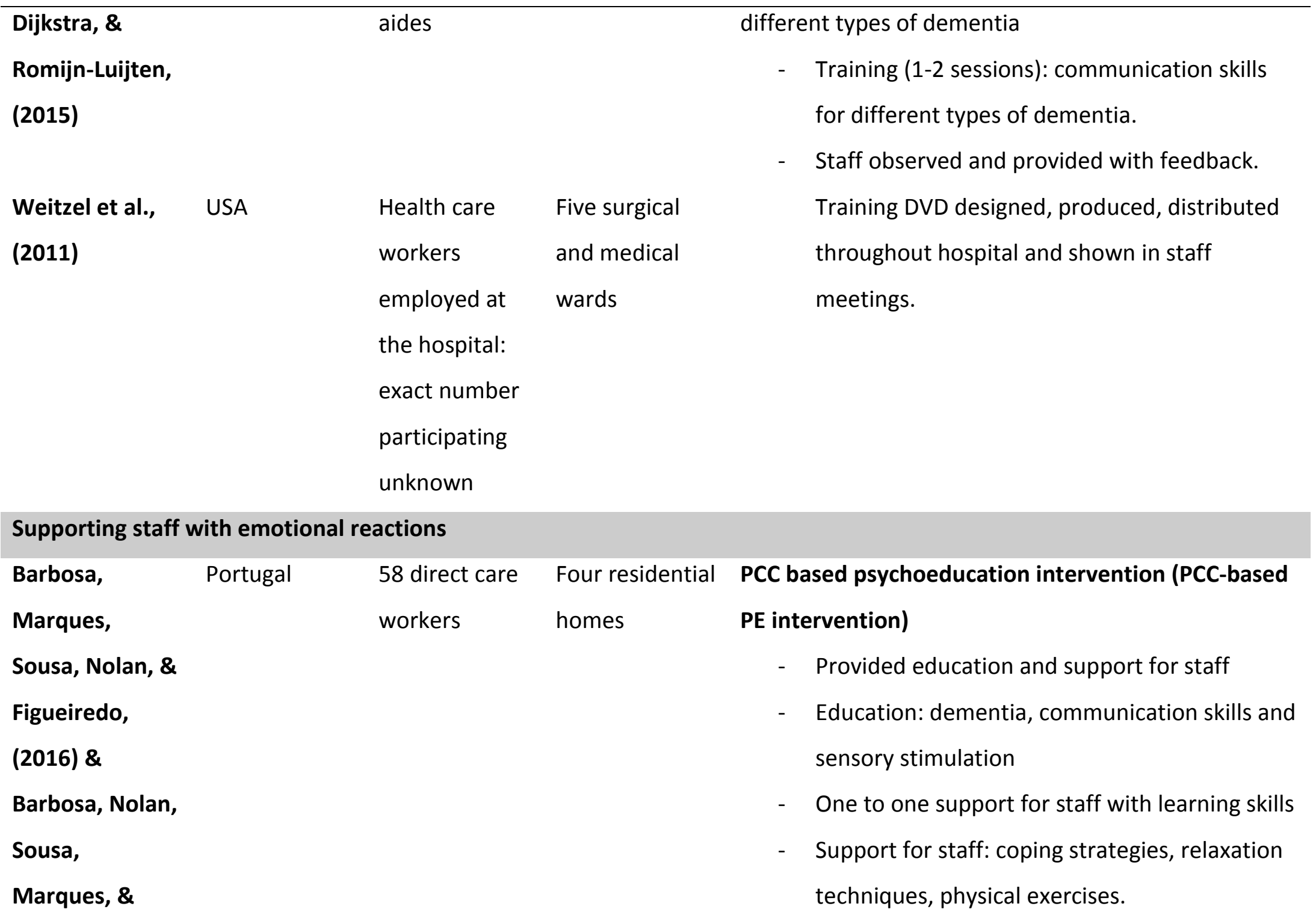




\begin{tabular}{|c|c|c|c|c|}
\hline $\begin{array}{l}\text { Figueiredo, } \\
\text { (2016)- } 6 \text { month } \\
\text { follow up study }\end{array}$ & & & & \\
\hline $\begin{array}{l}\text { Edberg, } \\
\text { Hallberg, \& } \\
\text { Gustafson, } \\
\text { (1996) }\end{array}$ & Sweden & $\begin{array}{l}39 \text { staff } \\
\text { members }\end{array}$ & $\begin{array}{l}\text { Two wards in a } \\
\text { psychogeriatric } \\
\text { clinic }\end{array}$ & $\begin{array}{l}\text { Systematic group clinical supervision focusing on } \\
\text { emotional reactions } \\
\begin{array}{l}\text { - } \\
\text { 2-day training session: dementia and care } \\
\text { planning } \\
\text { - } \quad \text { supervision covering emotional reactions } \\
\text { during care provision. }\end{array}\end{array}$ \\
\hline Dementia Care N & apping (DCI & & & \\
\hline $\begin{array}{l}\text { Brooker, Foster, } \\
\text { Banner, Payne, } \\
\text { \& Jackson, } \\
\text { (1998) }\end{array}$ & UK & $\begin{array}{l}\text { NHS staff: } \\
\text { number of } \\
\text { staff unknown }\end{array}$ & $\begin{array}{l}\text { Formal care } \\
\text { settings (acute } \\
\text { assessment, } \\
\text { respite, } \\
\text { continuing } \\
\text { care) within the } \\
\text { NHS trust }\end{array}$ & $\begin{array}{l}\text { - Units taking part in audit received DCM once a } \\
\text { year for three years: mapping, feedback, and } \\
\text { action planning } \\
\text { - Away days to review DCM data and amend } \\
\text { patient care plans. Action plans developed, } \\
\text { monitored and reviewed. }\end{array}$ \\
\hline $\begin{array}{l}\text { Chenoweth \& } \\
\text { Jeon, (2007) }\end{array}$ & Australia & $\begin{array}{l}\text { Staff and } \\
\text { managers at } \\
\text { the facilities: }\end{array}$ & $\begin{array}{l}3 \text { residential } \\
\text { dementia } \\
\text { services }\end{array}$ & $\begin{array}{l}\text { - Mapping, feedback, and action planning. } \\
\text { - } \quad \text { Assistance provided with care plans. } \\
\text { - Weekly phone calls for support. }\end{array}$ \\
\hline
\end{tabular}


number of

staff unknown

\begin{tabular}{|c|c|c|c|c|}
\hline $\begin{array}{l}\text { Jeon et al., } \\
\text { (2012) }\end{array}$ & Australia & $\begin{array}{l}124 \text { staff } \\
\text { members }\end{array}$ & $\begin{array}{l}15 \text { residential } \\
\text { care homes }\end{array}$ & $\begin{array}{l}\text { DCM } \\
\begin{array}{l}\text { - } \\
\text { - }\end{array} \text { Developping and feedback } \\
\text { residents } \\
\text { - } \quad \text { Telephone support from researchers } \\
\text { PCC intervention } \\
\text { - } \quad 2 \text { days of PCC training } \\
\text { - } \quad \text { Researchers supported staff with care } \\
\quad \text { planning and providing PCC to residents. } \\
\text { - } \quad \text { Telephone support. }\end{array}$ \\
\hline $\begin{array}{l}\text { Martin \& } \\
\text { Younger, (2001) }\end{array}$ & UK & $\begin{array}{l}\text { NHS staff } \\
\text { members: } \\
\text { number of } \\
\text { staff unknown }\end{array}$ & $\begin{array}{l}6 \text { day units, } 3 \\
\text { assessment } \\
\text { units, } 3 \\
\text { continuing care } \\
\text { units }\end{array}$ & Mapping, feedback, action planning \\
\hline
\end{tabular}

Interventions focused on retaining abilities

\begin{tabular}{|c|c|c|c|c|}
\hline $\begin{array}{l}\text { Galik, Resnick, } \\
\text { Hammersla, \& }\end{array}$ & USA & $\begin{array}{l}77 \text { nursing } \\
\text { assistants }\end{array}$ & $\begin{array}{l}\text { Four nursing } \\
\text { homes }\end{array}$ & $\begin{array}{l}\text { The Function Focused Care Intervention for the } \\
\text { cognitively impaired (FFC-Cl) }\end{array}$ \\
\hline
\end{tabular}


Brightwater,

(2013)

Galik, Resnick, USA

Lerner,

Hammersla, \&

Gruber-Baldini,

(2015)

Sidani, LeClerc, Canada

\& Streiner,

(2009)

$\&$

Sidani, Streiner,

\& LeClerc,

(2011)
- delivered by a function focused care nurse

(FFCN) working with experimental group.

- Local champions worked with FFCN.

- Education around FFC-Cl provided

- Collaborative goal setting

- Continued support to help staff with skills.

76 direct care Dementia See above

workers specific

assisted living

setting

79 staff Long term care

- Education session: teach staff Abilities

members institutions

Focused Morning Care (AFMC), explore effects

of dementia on resident abilities and how to

choose between different AFMC interventions 


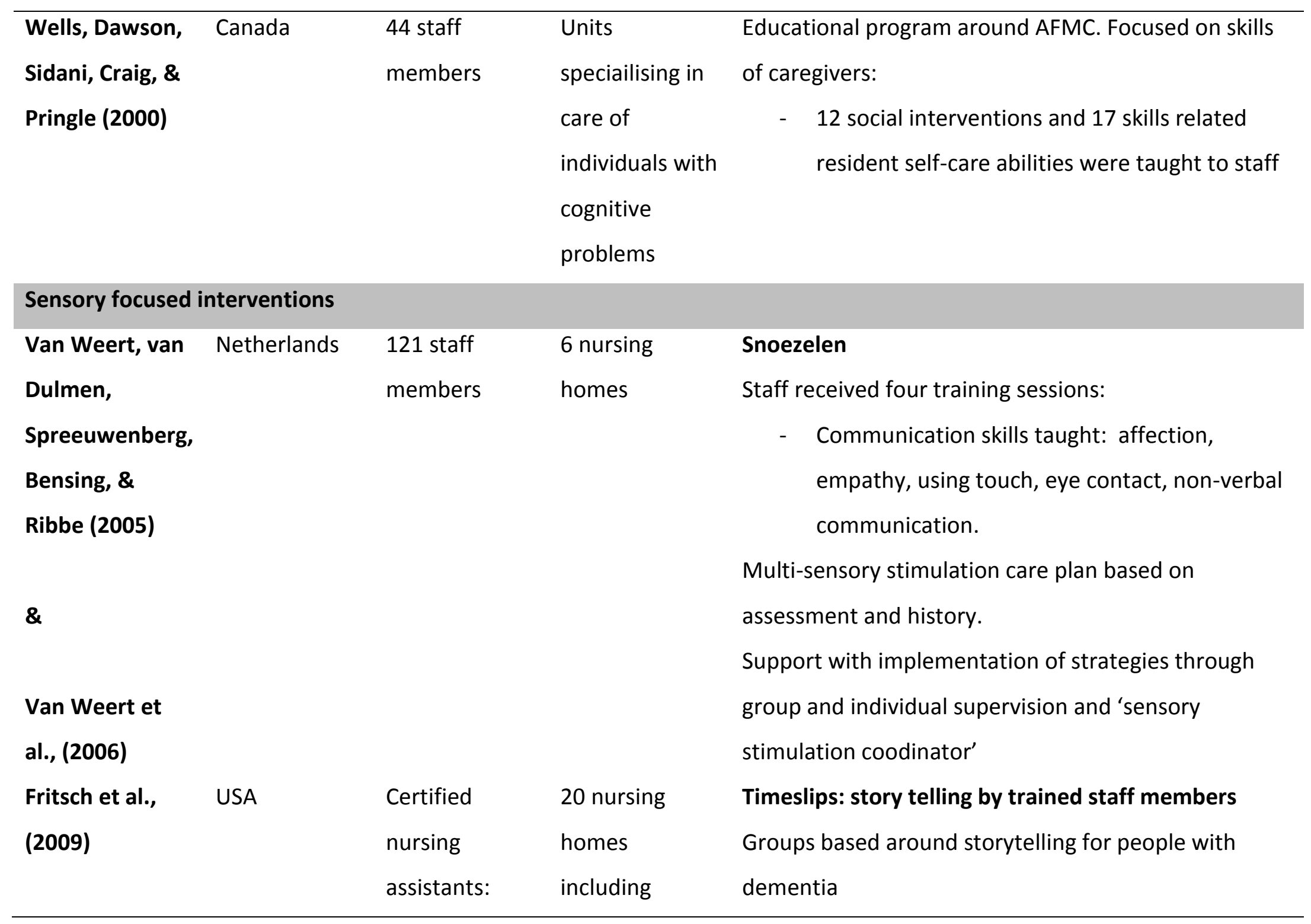




\begin{tabular}{|c|c|c|c|c|}
\hline & & $\begin{array}{l}\text { number of } \\
\text { staff unknown }\end{array}$ & $\begin{array}{l}\text { dementia } \\
\text { special care } \\
\text { units }\end{array}$ & $\begin{array}{l}\text { Led by trained facilitators } \\
\text { Staff trained in how to deliver 'Timeslips' }\end{array}$ \\
\hline \multicolumn{5}{|c|}{ Integrity Promoting Care } \\
\hline $\begin{array}{l}\text { Kihlgren, } \\
\text { Hallgren, } \\
\text { Norberg, Brane, } \\
\text { \& Karlsson, } \\
\text { (1990) }\end{array}$ & Sweden & $\begin{array}{l}\text { Staff team at } \\
\text { each enrolled } \\
\text { nursing home: } \\
\text { number of } \\
\text { staff unknown. } \\
\text { All staff on } \\
\text { experimental } \\
\text { ward } \\
\text { participated in } \\
\text { education } \\
\text { session }\end{array}$ & $\begin{array}{l}\text { Two wards at } \\
\text { two different } \\
\text { nursing homes }\end{array}$ & $\begin{array}{l}\text { Training in integrity promoting care } \\
\text { Key elements of course: } \\
\text { - } \quad \text { Eriksons (1982): discussions around promoting } \\
\text { integrity for people with dementia } \\
\text { - } \text { models of interaction and modifying } \\
\text { environment for person with dementia } \\
\text { discussed } \\
\text { Intervention period: } \\
\text { - Lectures and staff care video recorded } \\
\text { - } \quad \text { Researcher supported staff in changing } \\
\text { practice. }\end{array}$ \\
\hline $\begin{array}{l}\text { Kihlgren et al., } \\
\text { (1993) }\end{array}$ & Sweden & 10 caregivers & $\begin{array}{l}\text { Two wards at } \\
\text { two different } \\
\text { nursing homes }\end{array}$ & See above \\
\hline Systemic interve & tions & & & \\
\hline Edvardsson, & Sweden & 171 staff & Residential & - Discussed national dementia guidelines with all \\
\hline
\end{tabular}




\begin{tabular}{|c|c|c|c|c|}
\hline $\begin{array}{l}\text { Sandman, \& } \\
\text { Borell (2014) }\end{array}$ & & members & $\begin{array}{l}\text { aged care } \\
\text { facility }\end{array}$ & $\begin{array}{l}\text { staff and team analysis of strengths and } \\
\text { weaknesses conducted } \\
\text { - Staff from each unit supported to develop, } \\
\text { implement, and evaluate a change in staff PCC } \\
\text { behaviour. } \\
\text { - Findings shared with all colleagues across } \\
\text { facility. }\end{array}$ \\
\hline $\begin{array}{l}\text { Brooker, } \\
\text { Woolley, \& Lee, } \\
\text { (2007) }\end{array}$ & UK & $\begin{array}{l}\text { Staff working } \\
\text { in nursing } \\
\text { homes. } \\
\text { Number of } \\
\text { staff unknown }\end{array}$ & $\begin{array}{l}\text { Three } \\
\text { registered EMI } \\
\text { nursing homes }\end{array}$ & $\begin{array}{l}\text { Enriched opportunities program (Brooker \& Woolley, } \\
\text { 2007). } \\
\text { New member of staff recruited to lead intervention } \\
\text { and work with management } \\
\text { Staff training, one to one assessment and care } \\
\text { planning for people with dementia } \\
\text { Whole team provide more occupation for residents. }\end{array}$ \\
\hline Other & & & & \\
\hline $\begin{array}{l}\text { Boettcher, } \\
\text { Kemeny, } \\
\text { DeShon, \& } \\
\text { Stevens (2004) }\end{array}$ & USA & $\begin{array}{l}46 \text { certified } \\
\text { nursing } \\
\text { assistants }\end{array}$ & Nursing facility & $\begin{array}{l}\text { Person-centred care training course ( } 5 \text { modules) } \\
\text { Topics included: PPC, communication skills, and } \\
\text { behaviours that challenge } \\
\text { One to one input: observe demonstration and try out } \\
\text { skills. Feedback provided. }\end{array}$ \\
\hline
\end{tabular}




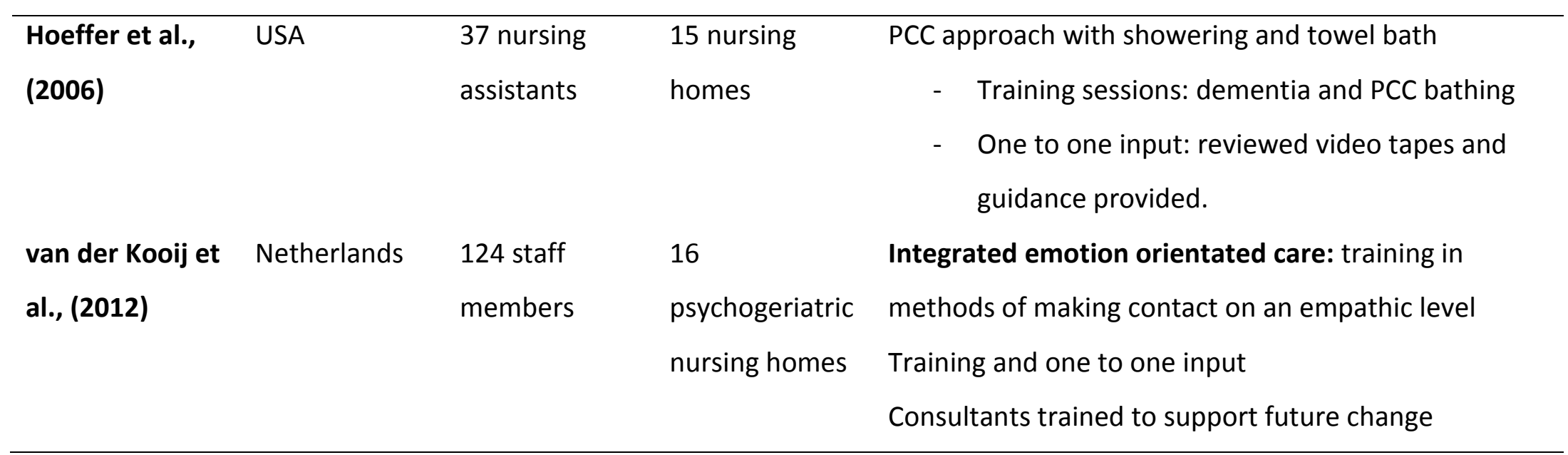

Key: Advanced Innovative Evidence-based Computer Education program (AllCE); Abilities Focused Morning Care (AFMC); Dementia Care Mapping (DCM); Elderly Mentally Infirm (EMI); Formal Staff Management (FSM); The Function Focused Care Intervention for the cognitively impaired (FFC-Cl); function focused care nurse (FFCN); Nursing Assistants (NA); Licensed Practice Nurses (LPN); Person Centred Care (PCC);

Psychoeducation (PE); Solution Focused Brief Therapy (SFBT); Valuing people, individualized care, personal perspectives, and social environment (VIPS). 
Research aim 2: Effectiveness of PCC interventions in increasing staff PCC behaviour

Details of the staff behaviour(s) measured, the overall quality, and the results of each study can be found in Table 2. Synthesised summaries of these findings for each group of interventions are presented blow.

\section{Communication training and/ or memory books}

Significant increases in staff PCC behaviour post intervention were found in nine out of the eleven studies, with effect sizes ranging from 0.01 to 1.22 . Within these nine studies, 65 out of the 100 variables measured showed significant improvement following implementation of the PCC intervention. However, seven out of the eleven studies in this category received an overall weak quality rating, reducing the confidence that can be placed in these results. Of the two studies that received a moderate quality rating, both showed significant improvements in at least some behaviours. For example, Bourgeois et al., (2004) found a significant improvement in nine out of 16 targeted PCC communication behaviours following the implementation of communication, memory books, and staff management training. In addition, Burglo et al., (2002) found significant improvement in six out of 23 target behaviours after implementing communication training in addition to training managers to observe their staff and provide feedback on how they communicate with people with dementia.

Of the two studies with strong ratings, one (Burgio et al., 2001) found significant evidence in favour of an intervention, which trained staff in communication skills and the use of memory books with residents, compared to the control group for four of the nine outcome variables. However, the other study (Sprangers et al., 2015) did not find any significant changes for the experimental group, who received communication skills training, over and above the control group. Burgio et al., (2001) implemented an intervention that was longer and had a greater number of parts, than the one implemented in Spranger et al., (2015), which may account for their different findings. In both of the interventions staff were observed and provided with feedback. However, in Burgio et al., (2001;2002) supervisors were trained in how to observe and provide feedback to their staff in line with the 
intervention, suggesting that communication skills training may be relatively more effective if it considers how to sustain change through the involvement of supervisors and the wider system (Burgio et al., 2001).

\section{Supporting staff with emotional reactions}

The three interventions in this category all used a two-group comparison design, and all showed significant increases in staff PCC behaviour following the intervention, with effect sizes ranging from 0.08 to 0.8 (Barbosa et al., (2016); Barbosa et al., (2016); Edberg et al, 1993). Edberg et al., (1993) report that the overall co-operation style of staff in the experimental group significantly improved following the intervention. However, both studies by Barbosa et al. (2016; 2016a) showed significant effects for the influence of the staff support component of their intervention on just two out of 26 variables measured. Barbosa et al., (2016) and Edberg et al., (1993) received a weak overall quality rating due to outcome assessors being aware of who had received the intervention, and limited information being provided on the validity of the methods the researchers used to code staff behaviour. Therefore, although all of these studies show positive and significant findings, it is not possible to be fully confident that increases in staff PCC behaviour were due to the interventions delivered.

$D C M$

Four studies investigated the effects of DCM (Brooker et al., 1998; Cheonweth and Jeon, 2009, Jeon et al., 2012 \& Martin and Younger, 2001). Three of the studies used a repeated measures design and only one study included a control group (Jeon et al., (2012).

Statistically significant increases in staff PCC behaviour were demonstrated in Brooker et al. (1998) and Cheonweth and Jeon (2009), but inferential statistics were not conducted on the variables of interest in Jeon et al. (2012) or Martin and Younger (2001). It was also only possible to calculate a single effect size $(d=0.03)$ for the change in well-being scores in Chenoweth and Jeon (2007). 
Encouragingly, increases in staff PCC behaviour can be seen when DCM is repeated and also captured by separate outcome measures. However, three out of four studies received a weak quality rating due to the lack of control groups. Chenoweth and Jeon (2007) received a moderate rating for their feasibility study, but more confident conclusions about DCM are hindered by the lack of data being provided by studies with a Randomised Controlled Trial design.

Interventions focused on retaining abilities

Five studies evaluated the impact of function-orientated staff training on staff PCC behaviour. Two studies were cluster randomized controlled trials (Galik et al, 2013; Galik et al 2015), one used a quasi-experimental design (Wells et al, 2000) and two studies were one group pre-test post-test designs (Sidani et al; 2009; 2012). Four studies found evidence of effectiveness for this class of interventions in improving staff PCC behaviour, with effect sizes ranging from 0.15 to 1.00 , and only one study (Sidani et al, 2009) received a weak quality rating, with the remaining studies receiving a moderate rating. Combining the variables measured in Sidani et al., $(2009 ; 2012)$ and Wells et al., (2000), 10 out of 16 target variables significantly improved following the implementation of the intervention. The studies by Wells et al., (2000) and Galik et al., (2015) were influenced by confounding variables as there were baseline differences between their control and experimental groups. In addition, they did not find an effect of the intervention in an assisted living setting. This group of studies suggest that interventions focused on retaining skills may be more effective when applied in residential and nursing homes (Galik et al., 2013; Sidani et al, 2009; Sidani et al., 2011).

\section{Sensory-focused interventions}

Three studies explored the impact of training staff in sensory based interventions, which involved providing multisensory stimulation or group programs for people with dementia that aimed to activate different senses. Van Weert et al., $(2005 ; 2006)$ used a clusterrandomised design and Fritsch et al., (2009) used a two-group comparison design. There 
were significant increases in staff PCC behaviour across all three of the sensory stimulation interventions, with effect sizes ranging from 0.52 to 0.66 . However, Van Weert et al., (2006) and Fritsch et al., (2009) received a weak in comparison to a moderate (Van Weert et al, $20005)$ quality rating. In Van Weert et al., $(2005 ; 2006) 26$ out of 62 target variables significantly increased following the implementation of Snoezelen. However in Van Weert et al., (2005) wards were randomized before individual participants received pre-test assessments resulting in possible selection bias. It is also difficult to track the movement of participants through Van Weert et al $(2005 ; 2006)$ as dropouts in participant and staff member groups are replaced with new members throughout the intervention period. Therefore, the extent to which changes in staff PCC behaviour are due to the sensory focused interventions is unclear.

Integrity-promoting care

This category contained two studies by Kihlgren et al. (1990) and Kihlgren et al. (1993), both of which used quasi-experimental designs to investigate the effect of training staff in integrity promoting care on the quality of morning care. Both of the studies reported increases in observed staff PCC behaviour. However, a lack of inferential statistics, and the weak quality ratings of these studies, makes it difficult to make any judgement about the impact of training in integrity promoting care on staff PCC behaviour.

\section{Systemic interventions}

Two studies using a pre and post test design explored interventions that aimed to influence the care provided over a whole facility. Edvardsson et al., (2014) supported staff from multiple units to come together to share practice improvements. Brooker et al., (2007) also employed a specialist "locksmith" member of staff who could work alongside direct care workers and management to model PCC approaches. Both of these studies found statistically significant increases in desired staff PCC behaviour with effect sizes ranging from 0.13 to 0.71 . All of these interventions received a moderate rating, with the influence of confounding variables being difficult to assess due to the lack of a control group. 
Other

Hoeffer et al., (2006) used an RCT to investigate an intervention to enhance person centred bathing, and found that staff were gentler according to the CBBRS, after they had been trained in a PCC bathing method. Van der Kooij et al., (2012) used an RCT design to assess the effectiveness of emotion - orientated care and found that staff expertise in performing emotion-orientated care skills significantly improved at follow up. Boettcher et al., (2004) used a one group pre-test post-test design to examine the impact of a PCC training course on staff PCC behaviour and four out of seven variables significantly improved after staff had attended the course. However, this study received a 'weak' overall quality rating, thus making it difficult to make a judgement about effectiveness. 
Table 2. Summary of results

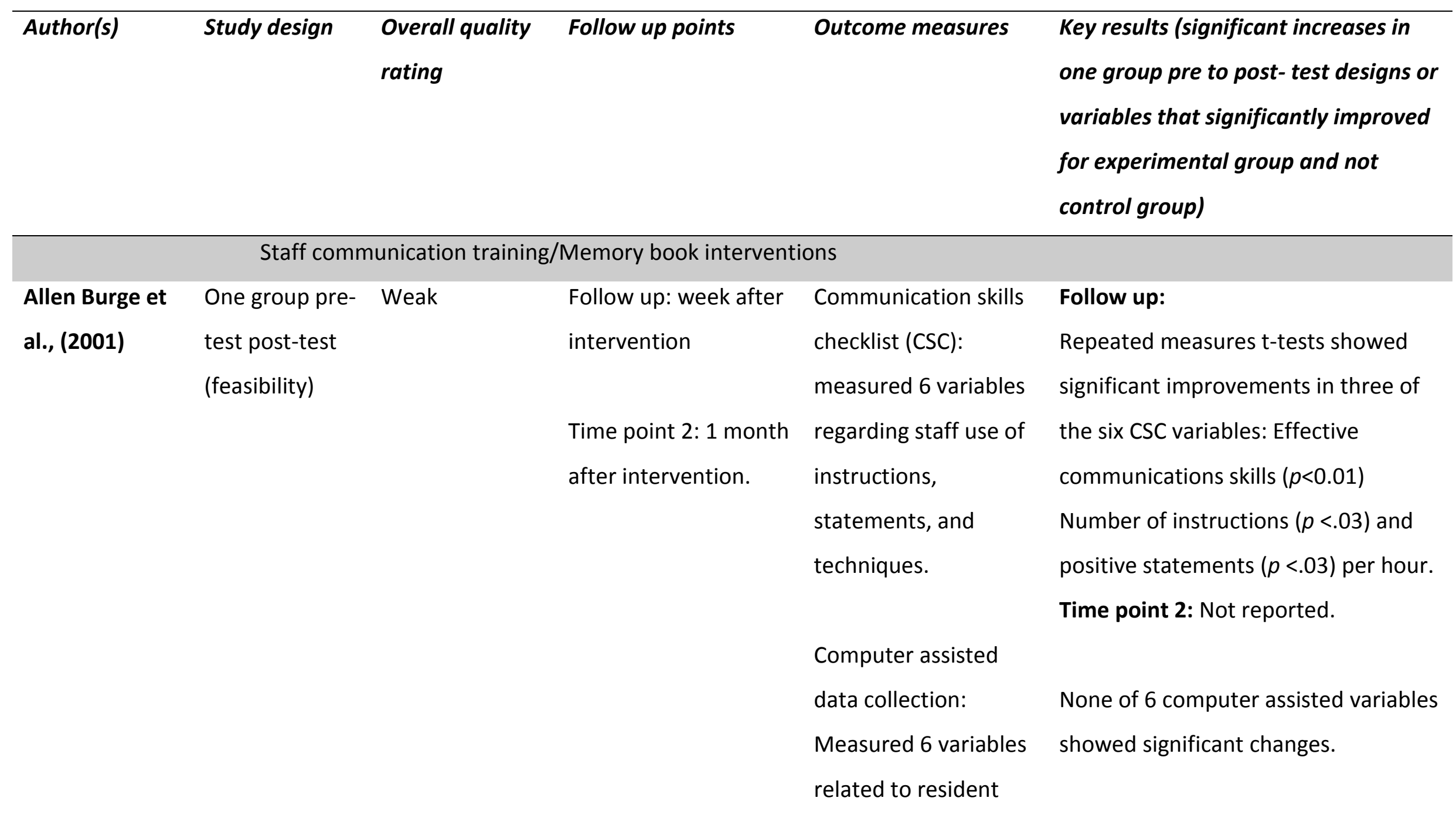




\begin{tabular}{|c|c|c|c|c|c|}
\hline & & & & environment. & \\
\hline Boscart, (2009) & $\begin{array}{l}\text { One group pre- } \\
\text { test post-test }\end{array}$ & Weak & $\begin{array}{l}5 \text { months after } \\
\text { intervention }\end{array}$ & $\begin{array}{l}\text { Conversations } \\
\text { between staff and } \\
\text { patients, analysed for } \\
5 \text { variables }\end{array}$ & $\begin{array}{l}\text { Chi-square tests showed significant } \\
\text { increases for all } 5 \text { variables }(p=0.001)\end{array}$ \\
\hline \multirow[t]{3}{*}{$\begin{array}{l}\text { Bourgeois et } \\
\text { al., (2003) }\end{array}$} & $\begin{array}{l}\text { Two group } \\
\text { comparison }\end{array}$ & Moderate & $\begin{array}{l}\text { Follow up: post } \\
\text { training: one week } \\
\text { following intervention }\end{array}$ & $\begin{array}{l}\text { CSC: measured } 12 \\
\text { communication skill } \\
\text { variables }\end{array}$ & $\begin{array}{l}\text { Follow up: } \\
\text { Repeated measures ANOVAs and t- } \\
\text { tests used to show that }\end{array}$ \\
\hline & $\begin{array}{l}\text { Type of control } \\
\text { not stated }\end{array}$ & & $\begin{array}{l}\text { Time point 2: } 3 \\
\text { months }\end{array}$ & $\begin{array}{l}\text { Computer assisted } \\
\text { observational system } \\
\text { (CABOS): } \\
\text { measured } 4 \text { variables }\end{array}$ & $\begin{array}{l}7 \text { out of } 12 \text { CSC variables significantly } \\
\text { improved for the experimental group } \\
\text { only. Significance values and effect } \\
\text { sizes ranged from } p<.001, d=0.34 \text { to } \\
p<.05, d=152.6 \text {. }\end{array}$ \\
\hline & & & & & $\begin{array}{l}\text { Two out of } 4 \text { CABOS variables } \\
\text { significantly improved for } \\
\text { experimental group only }(p<.05) \\
\text { Time point 2: } \\
\text { Maintained differences for } 4 \\
\text { variables. Significance values ranged }\end{array}$ \\
\hline
\end{tabular}




\begin{tabular}{|c|c|c|c|c|c|}
\hline & & & & & from $p<.001$ to $p<.05$ \\
\hline \multirow{15}{*}{$\begin{array}{l}\text { Burgio et al., } \\
\text { (2001) }\end{array}$} & Two group & Strong & Follow up:1-4 weeks & CSC measured 5 & Follow up: \\
\hline & comparison & & post intervention & variables & ANOVAs showed significant \\
\hline & & & & & improvements in 2 of the 5 CSC \\
\hline & & & Time point 2: $5-7$ & CABOS: measured 4 & variables: \\
\hline & & & weeks post & variables & Overall correct communication skills \\
\hline & & & intervention & & $(p=.0001)$ \\
\hline & & & & & Positive statements $(p=.004)$ \\
\hline & & & & & CABOS: ANOVAs showed significant \\
\hline & & & & & improvement in 2 of the 4 variables \\
\hline & & & & & Speech towards residents $(p=.02)$ \\
\hline & & & & & Positive interactions with residents \\
\hline & & & & & $(p=.01)$ \\
\hline & & & & & Time point 2: \\
\hline & & & & & Differences maintained between \\
\hline & & & & & groups for above variables. \\
\hline \multirow{4}{*}{$\begin{array}{l}\text { Burgio et al., } \\
\text { (2002) }\end{array}$} & Randomized & Moderate & Follow up: Post & Behaviour & Follow up: \\
\hline & controlled trial & & intervention & management skills & ANCOVAs showed that 5 out of 18 \\
\hline & & & & checklist (BMSC): & BMSC variables increased in desirable \\
\hline & FSM: training & & Time point 2: 3 & measured 18 & direction for experimental group only. \\
\hline
\end{tabular}




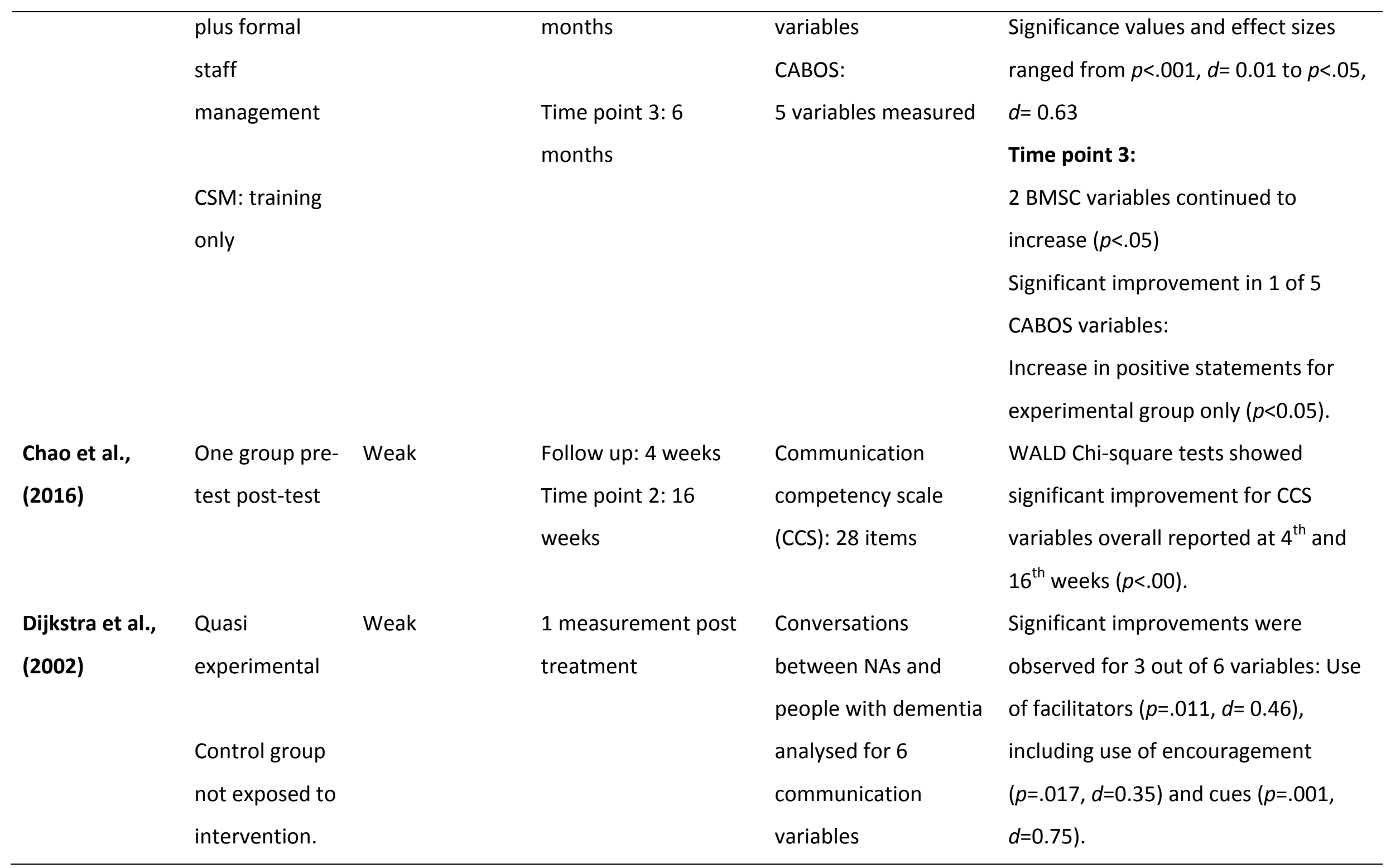




\begin{tabular}{|c|c|c|c|c|c|}
\hline $\begin{array}{l}\text { Hoerster et al., } \\
\text { (2001) }\end{array}$ & $\begin{array}{l}\text { Multiple } \\
\text { baseline }\end{array}$ & Weak & $\begin{array}{l}\text { Staff received } 2 \text { sets } \\
\text { of instructions: timing } \\
\text { of instructions not } \\
\text { stated }\end{array}$ & $\begin{array}{l}\text { Recordings of staff- } \\
\text { resident } \\
\text { conversations } \\
\text { examined for rate of } \\
\text { NA } \\
\text { Communication } \\
\text { behaviours }\end{array}$ & $\begin{array}{l}\text { No inferential statistics. Reduction in } \\
\text { requests or assertations or both } \\
\text { noted when memory aid present }\end{array}$ \\
\hline $\begin{array}{l}\text { Passalacqua \& } \\
\text { Harwood, } \\
\text { (2012) }\end{array}$ & $\begin{array}{l}\text { One group pre- } \\
\text { test post-test } \\
\text { design }\end{array}$ & Weak & $\begin{array}{l}6 \text { weeks following } \\
\text { intervention }\end{array}$ & $\begin{array}{l}\text { self-report measure } \\
\text { on use of } 14 \text { PCC } \\
\text { communication skills }\end{array}$ & $\begin{array}{l}\text { ANCOVAs and repeated measures t- } \\
\text { tests used to show significant } \\
\text { improvement in } 3 \text { of the } 6 \text { variables: } \\
\text { Gestures ( } p<0.05, d=0.69 \text { ), asking } \\
\text { yes/no questions ( } p<0.05, d=0.56 \text { ) and } \\
\text { giving a choice between two options } \\
(p<0.05, d=0.47)\end{array}$ \\
\hline $\begin{array}{l}\text { Sprangers et } \\
\text { al., (2015) }\end{array}$ & $\begin{array}{l}\text { Two group } \\
\text { comparison } \\
\text { Control: } 1 \text { ward }\end{array}$ & Strong & $\begin{array}{l}\text { Baseline to post } \\
\text { intervention was } 8 \\
\text { weeks }\end{array}$ & $\begin{array}{l}\text { Observation Form of } \\
\text { General } \\
\text { Communication } \\
\text { (OFGC): measured } 4\end{array}$ & $\begin{array}{l}\text { ANOVAs revealed there to be no } \\
\text { significant interactions }\end{array}$ \\
\hline
\end{tabular}




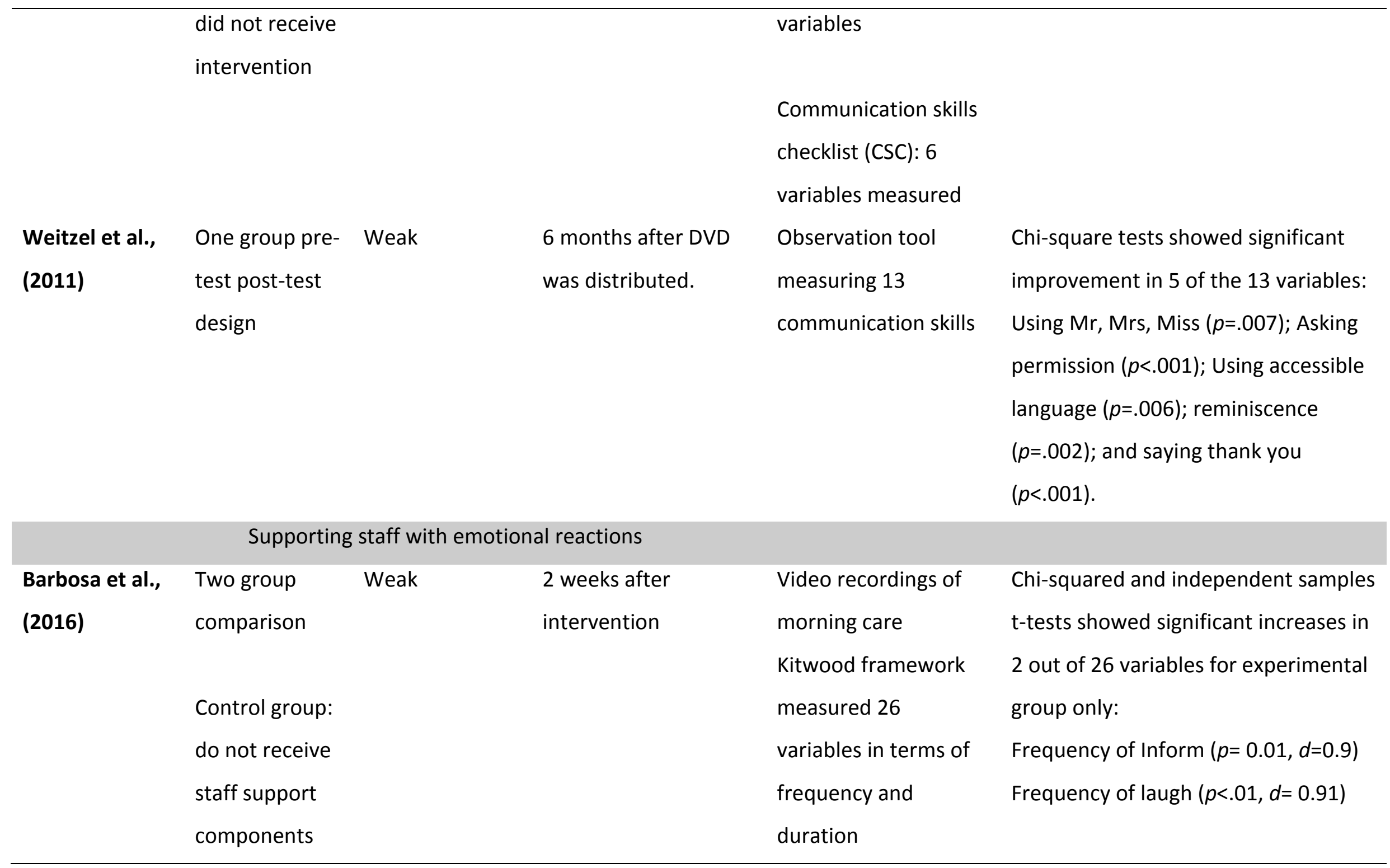




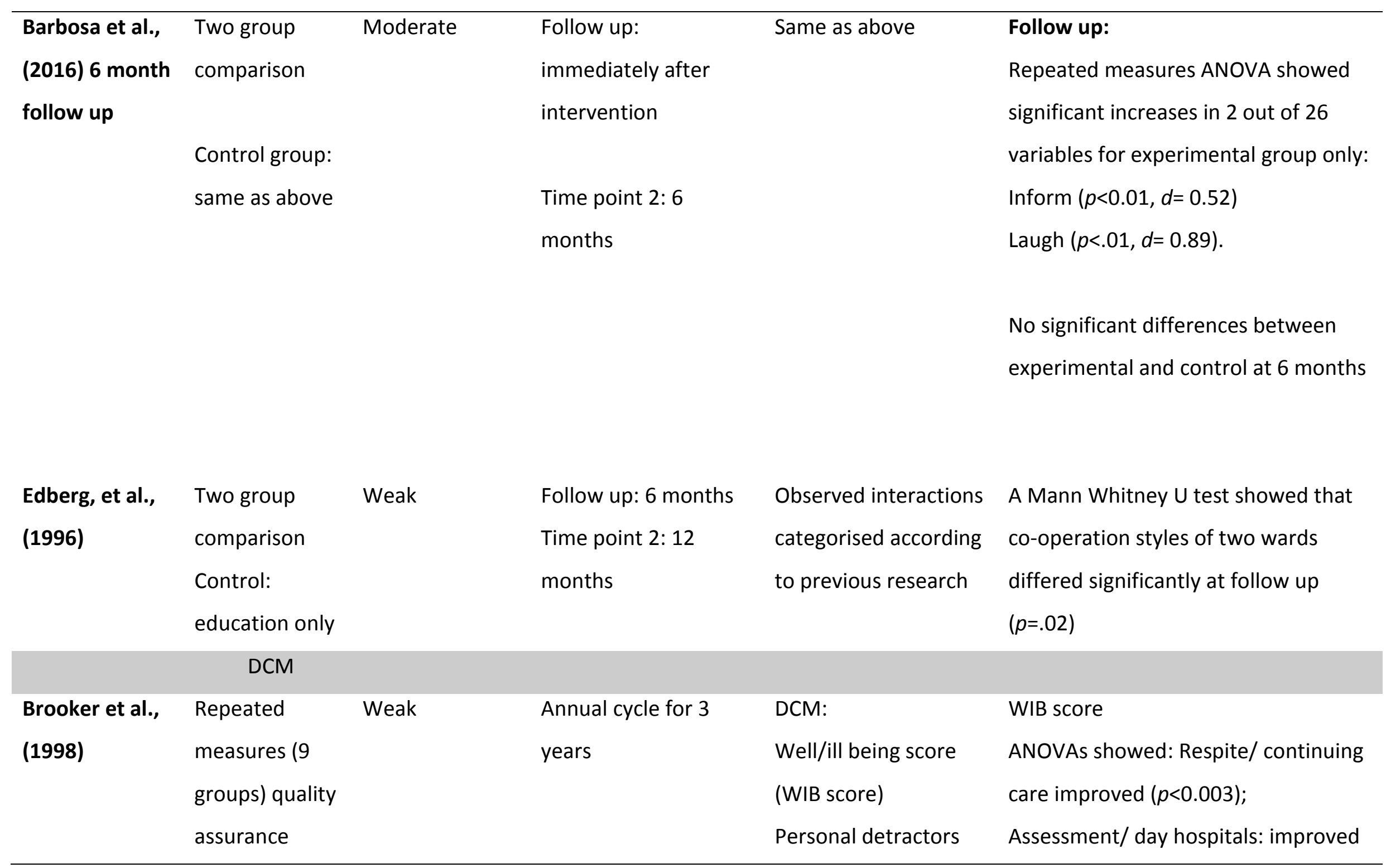




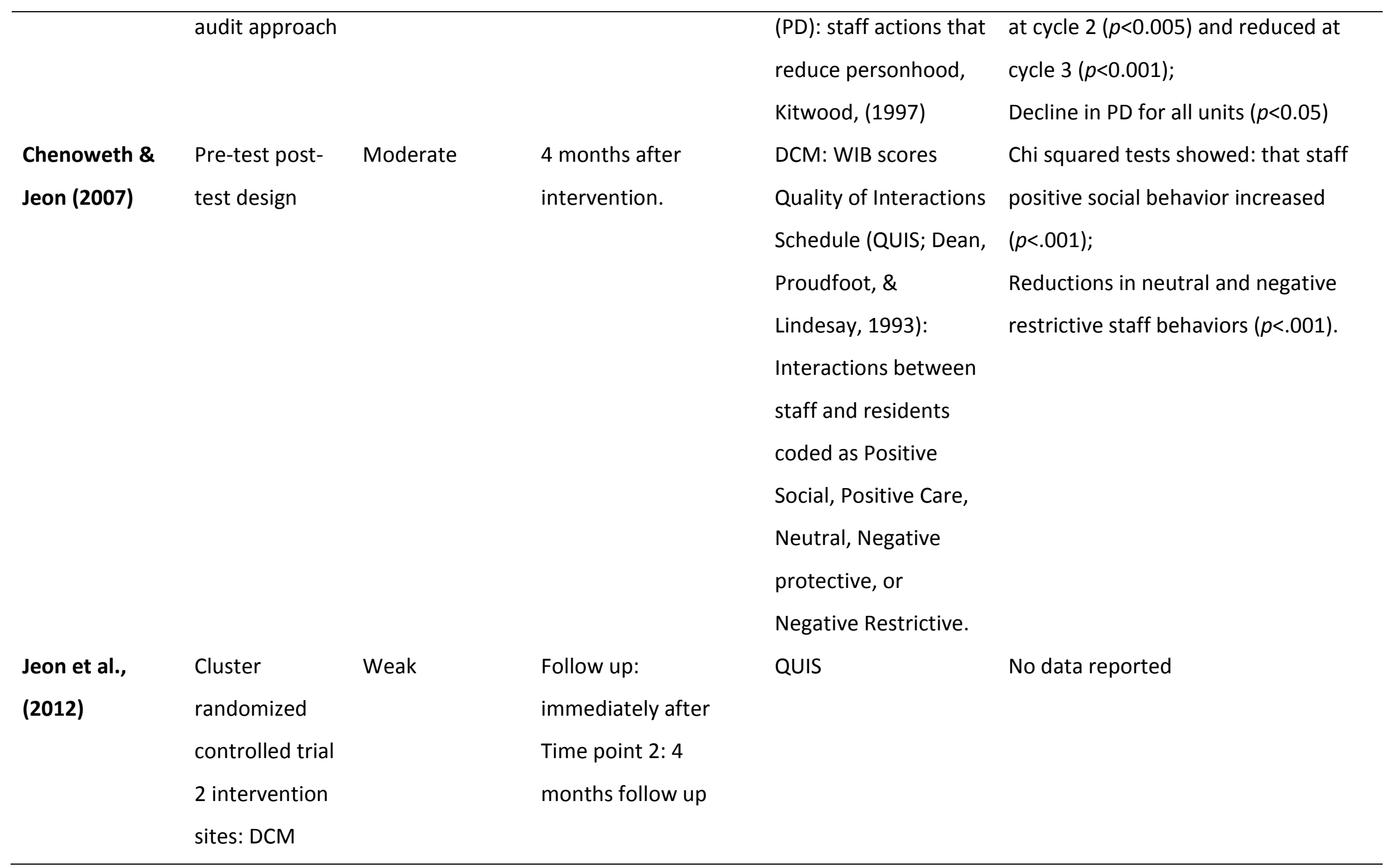


compared to

PCC

intervention

1 control site:

care as usual

\begin{tabular}{|c|c|c|c|c|c|}
\hline $\begin{array}{l}\text { Martin \& } \\
\text { Younger, } \\
\text { (2001) }\end{array}$ & $\begin{array}{l}\text { One group pre- } \\
\text { test post-test. }\end{array}$ & Weak & Follow up: 1 year. & $\begin{array}{l}\text { WIB scores Dementia } \\
\text { Care Index (DCI): } \\
\text { assesses nature of } \\
\text { interactions between } \\
\text { staff and patients }\end{array}$ & $\begin{array}{l}\text { No inferential statistics. Mean WIB } \\
\text { scores increased from } 1.4 \text { in } 1999 \text { to } \\
1.9 \text { in } 2000 \text {. Mean DCl scores } \\
\text { increased from } 39.6 \text { in } 1999 \text { to } 47.5 \text { in } \\
2000 .\end{array}$ \\
\hline \multicolumn{6}{|c|}{ Interventions focused on retaining abilities } \\
\hline $\begin{array}{l}\text { Galik, et al., } \\
\text { (2013) }\end{array}$ & $\begin{array}{l}\text { Cluster } \\
\text { randomized } \\
\text { controlled trial. } \\
\text { Control: } \\
\text { education only }\end{array}$ & Moderate & $\begin{array}{l}\text { Follow up: } 3 \text { months } \\
\text { from baseline } \\
\text { Time point 2: } 6 \\
\text { months }\end{array}$ & $\begin{array}{l}\text { Restorative Care } \\
\text { Behaviour checklist } \\
\text { (RCBC): observation } \\
\text { instrument- } \\
\text { calculated how much } \\
\text { time staff spent } \\
\text { delivering function } \\
\text { focused care }\end{array}$ & $\begin{array}{l}\text { Time point 2: ANOVA showed that } \\
\text { the percentage of time staff } \\
\text { performed FFC ( } p=.001 \text { ) increased in } \\
\text { experimental group only. }\end{array}$ \\
\hline Galik et al., & Cluster & Moderate & Follow up: 3 months & see above & ANOVA showed no significant \\
\hline
\end{tabular}




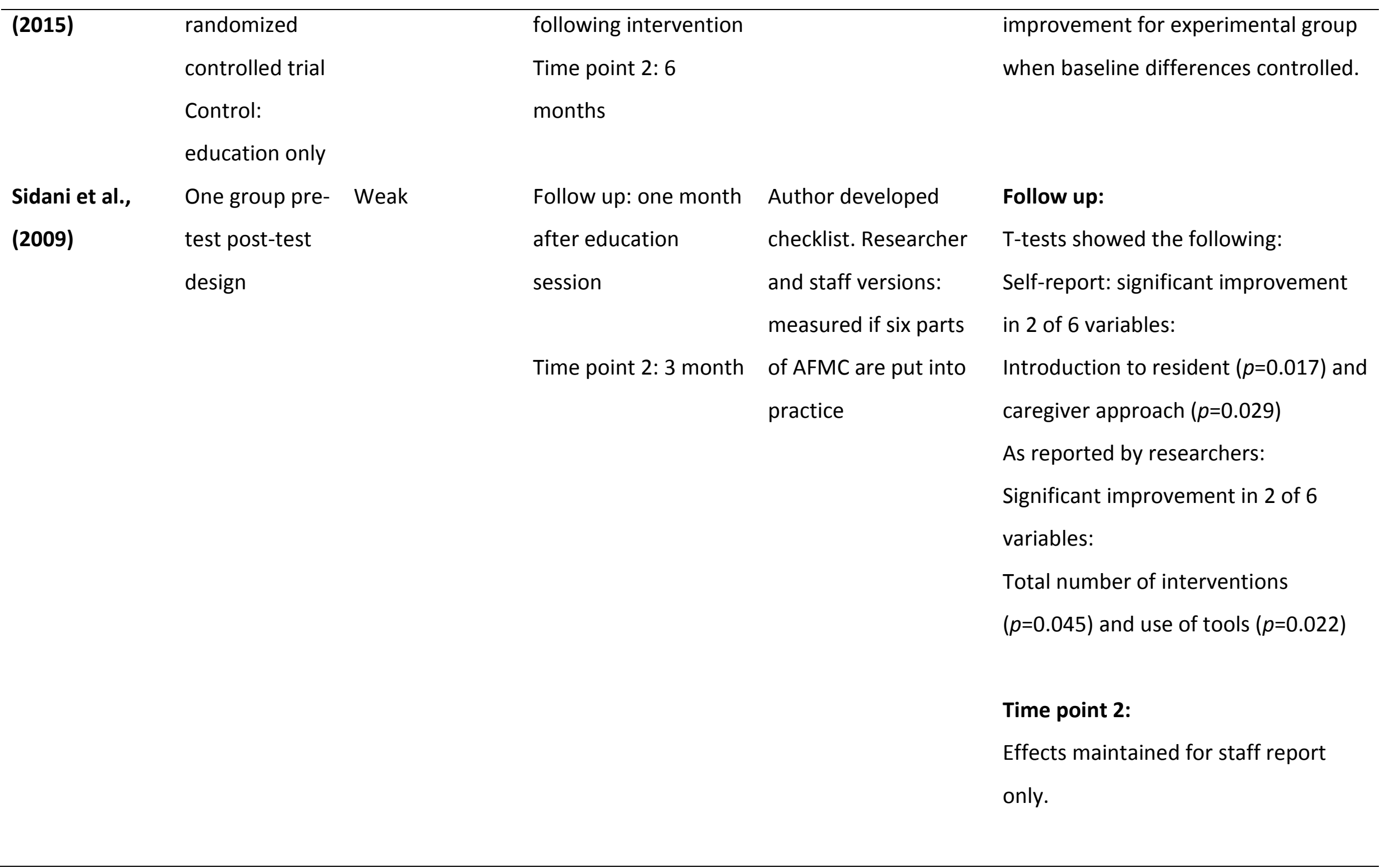




\begin{tabular}{|c|c|c|c|c|c|}
\hline $\begin{array}{l}\text { Sidani et al., } \\
\text { (2011) }\end{array}$ & $\begin{array}{l}\text { One group pre- } \\
\text { test post-test } \\
\text { design }\end{array}$ & Moderate & $\begin{array}{l}\text { Follow up: } 1 \text { month } \\
\text { after AFMC session }\end{array}$ & See above & $\begin{array}{l}\text { T-tests showed that } 5 \text { of } 6 \text { variables } \\
\text { significantly increased. Significance } \\
\text { level and effect sizes ranged from } \\
p<.001, d=0.15 \text { to } p<.05, d=0.5 \text {. }\end{array}$ \\
\hline $\begin{array}{l}\text { Wells et al., } \\
(2000)\end{array}$ & $\begin{array}{l}\text { Quasi } \\
\text { experimental } \\
\text { design } \\
\text { Control: usual } \\
\text { care }\end{array}$ & Moderate & $\begin{array}{l}\text { Follow up: } 3 \text { months } \\
\text { Time point 2: } 6 \\
\text { months }\end{array}$ & $\begin{array}{l}\text { Interaction behaviour } \\
\text { Measure (IBM): } 4 \\
\text { variables }\end{array}$ & $\begin{array}{l}\text { Repeated measures ANOVAs showed } \\
\text { significant increases for } 3 \text { of } 4 \\
\text { variables in experimental group only } \\
\text { ( } p=.003, d=0.57 \text { to } p=.026, d=1.00) \\
\text { Differences in social/ flexible } \\
\text { behaviours due to control groups } \\
\text { decline. }\end{array}$ \\
\hline $\begin{array}{l}\text { van Weert, et } \\
\text { al., (2005) }\end{array}$ & $\begin{array}{l}\text { Quasi } \\
\text { experimental } \\
\text { design } \\
\text { Control: usual } \\
\text { care }\end{array}$ & Moderate & 18 months & $\begin{array}{l}31 \text { variables } \\
\text { measured in total } \\
\text { Video assessment of } \\
\text { non-verbal variables } \\
\text { Roter Interaction } \\
\text { Analysis System }\end{array}$ & $\begin{array}{l}\text { Chi-square tests or t-tests used to } \\
\text { show: } \\
5 \text { of } 31 \text { non-verbal variables } \\
\text { significantly improved for } \\
\text { experimental group only (all at } p<.001 \\
\text { level) }\end{array}$ \\
\hline
\end{tabular}


(RIAS): 19 categories

for staff verbal

behaviour.

18 months

care

Observation

person work and 12 experimental

design

Control: care

as usual.

Weak

al., (2006)

Fritsch, T.,

Kwack, Y.,
Two group Weak

comparison
12 of 19 verbal variables significantly improved for experimental group

only, with levels of significance

ranging from $p<0.05$ to $p<0.001$

Videotaped morning Chi-square tests or t-tests used to

show that:

Positive person work $(d=0.66)$ :

measured 10 positive

Significant increase for experimental

group only on all $10 \mathrm{PPW}$ variables.

malignant social

$(p<0.05$ to $p<0.001)$

psychology variables. Malignant social psychology $(d=$

0.52 ): 9 of 12 variables significantly reduced in experimental group and increased in control group ( $p<0.001$ to $p<.05)$.

Sensory stimulation: increased in experimental group only $(p<0.001)$. Chi-square tests showed that 4 variables significantly increased at 


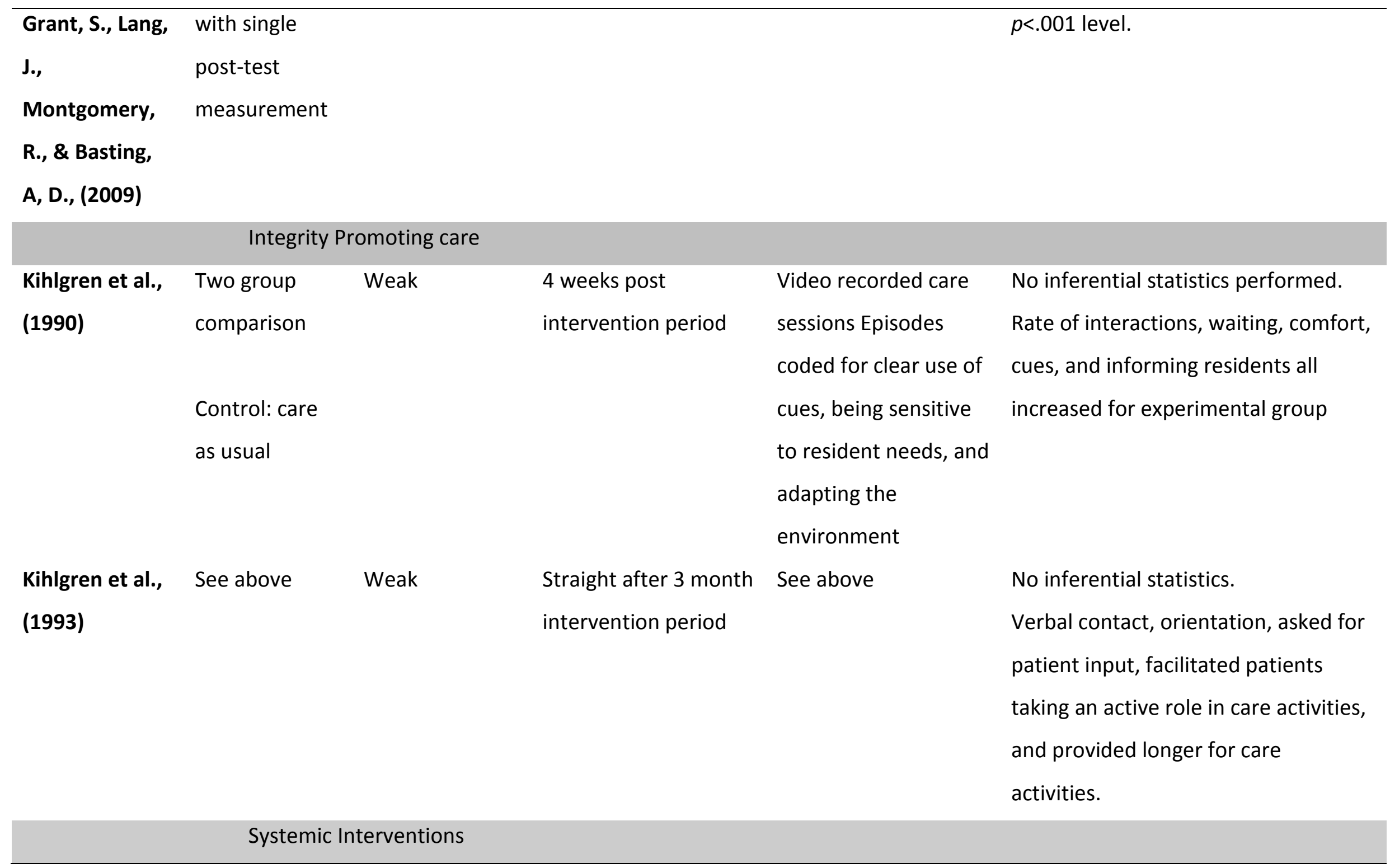




\begin{tabular}{|c|c|c|c|c|c|}
\hline $\begin{array}{l}\text { Edvardsson, D., } \\
\text { Sandman, P, } \\
\text { O., \& Borell, L., } \\
\text { (2014) }\end{array}$ & $\begin{array}{l}\text { One group pre- } \\
\text { test post-test } \\
\text { design }\end{array}$ & Moderate & 12 month follow up & $\begin{array}{l}\text { Person centred care } \\
\text { assessment tool } \\
\text { (PCAT): } 13 \text { items } \\
\text { Person centred } \\
\text { climate questionnaire } \\
\text { (PCQ): } 17 \text { items }\end{array}$ & $\begin{array}{l}\text { Repeated measures t-tests used to } \\
\text { show: } \\
\text { PCAT: } \\
\text { Overall score significantly increased } \\
\text { ( } p<0.01, d=0.34 \text { ) } \\
2 \text { Subscales significantly increased: } \\
p=0.03, d=0.26 \& \\
p=0.05, d=0.23 \\
\text { PCQ: } \\
\text { Overall score significantly increased } \\
\text { ( } p=0.26, d=0.13 \text { ) }\end{array}$ \\
\hline $\begin{array}{l}\text { \& Lee, D., } \\
\text { (2007) }\end{array}$ & groups) design & & $\begin{array}{l}\text { Time point 2: } 7 \\
\text { months } \\
\text { Time point 3: 7-14 } \\
\text { months. }\end{array}$ & $\begin{array}{l}\text { Positive events: } \\
\text { Reflecting staff PCC } \\
\text { behaviour } \\
\text { Personal detractors }\end{array}$ & $\begin{array}{l}\text { WIB scores: Increase at } 2 \text { sites } \\
(p=0.001) \text { and decreased at } 1 \\
(p=0.002) \\
\text { Positive events increased }(p=0.001, d= \\
0.71) \\
\text { Time point 3: }\end{array}$ \\
\hline
\end{tabular}


WIB scores:

Increased for one site $(p=0.001)$ and

other two combined ( $p=0.028)$.

Positive events increased $(p=.001$ to

$p=.002)$

\begin{tabular}{|c|c|c|c|c|c|}
\hline & Other & & & & \\
\hline $\begin{array}{l}\text { Boettcher et } \\
\text { al., (2004) }\end{array}$ & $\begin{array}{l}\text { One group pre- } \\
\text { test post-test }\end{array}$ & Weak & $\begin{array}{l}2 \text { months after } \\
\text { training. }\end{array}$ & $\begin{array}{l}\text { Behaviourally } \\
\text { anchored rating scales } \\
\text { (BARS): } \\
\text { Measured seven } \\
\text { variables. }\end{array}$ & $\begin{array}{l}\text { T-tests showed that } 4 \text { out of } 7 \\
\text { variables significantly increased (all } \\
p<.05)(d=1.12 \text { to } d=1.78 \text { ), }\end{array}$ \\
\hline $\begin{array}{l}\text { Hoeffer et al., } \\
\text { (2006) }\end{array}$ & $\begin{array}{l}\text { Randomised } \\
\text { controlled trial: } \\
\text { Control: care } \\
\text { as usual }\end{array}$ & Moderate & $\begin{array}{l}\text { Follow up: } 6 \text { weeks, } \\
\text { time point 2: } 12 \\
\text { weeks }\end{array}$ & $\begin{array}{l}\text { The Caregiver Bathing } \\
\text { Behaviour Rating } \\
\text { Scale (CBBRS) } \\
\text { Measures } 2 \text { variables }\end{array}$ & $\begin{array}{l}\text { ANOVAs showed increased gentleness } \\
(p<.01) \text { for shower and towel bath } \\
\text { conditions. }\end{array}$ \\
\hline $\begin{array}{l}\text { van der Kooij } \\
\text { et al., (2012) }\end{array}$ & $\begin{array}{l}\text { Randomised } \\
\text { controlled trial: } \\
\text { control: usual } \\
\text { care }\end{array}$ & Moderate & $\begin{array}{l}\text { Follow up at } 7 \\
\text { months. }\end{array}$ & $\begin{array}{l}\text { Emotion orientated } \\
\text { Skills in interaction } \\
\text { with the elderly } \\
\text { (ESID): Self-report } \\
\text { measured } 22\end{array}$ & $\begin{array}{l}\text { MANCOVA showed an increase in } \\
\text { staff 'expertise' at implementing } \\
\text { techniques focused on the emotional } \\
\text { experiences of the people they were } \\
\text { caring for ( } p=0.001, d=0.39 \text { ). }\end{array}$ \\
\hline
\end{tabular}


Key: Behaviourally anchored rating scales (BARS); Behaviour management skills checklist (BMSC); The Caregiver Bathing Behaviour Rating Scale (CBBRS); Communication skills checklist (CSC); Computer assisted observational system (CABOS); Communication competency scale (CCS); Conventional Staff Management (CSM); Dementia Care Mapping (DCM); Dementia Care Index (DCI); Emotion orientated Skills in interaction with the elderly (ESID); Function Focused Care (FFC); Formal Staff Management (FSM); Function Focused Care (FFC); Interaction Behaviour Measure (IBM); Nursing assistants (NAs); Observation Form of General Communication (OFGC); Person Centred Care (PCC); Personal detractors (PD); Person centred care assessment tool (PCAT); Person centred climate questionnaire (PCQ); Quality of Interactions Schedule (QUIS); Roter Interaction Analysis System (RIAS); Restorative Care Behaviour checklist (RCBC); Well/ill being score (WIB score); Positive Person Work (PPW); Malignant Social Psychology (MSP). 


\section{DISCUSSION}

This review adds to the literature in a number of ways. First, it has identified and categorised a wide range of interventions that target PCC. This builds on the types of intervention identified by Fossey et al., (2014), Low et al., (2015) and Bird et al., (2016), and also provide a provisional categorisation system that can be used to aid the review and selection of future PCC interventions. Furthermore, although limited by the quality of the evidence base identified, we were able to draw some initial conclusions regarding the effectiveness of each type of intervention. This suggested that there is at least some evidence for the effectiveness of communication training; supporting staff with emotional reactions; Dementia Care Mapping; interventions focused on retaining abilities; sensory focused interventions; systemic interventions; as well as those categorised as 'other' types of intervention. The lack of inferential statistics conducted for the studies evaluating the effectiveness of training in integrity promoting care, and the weak quality rating of the single study assessing a PCC training course, prevented any judgements about the effectiveness of these approaches being made.

Another contribution of this review is that it has identified the effectiveness of PCC interventions on a diverse range of PCC behaviours. For instance, the breadth of staff PCC behaviour that was shown to improve following these interventions included improved verbal and non-verbal communication, increases in positive person work (informing people with dementia about their care and the use of laughter), reductions in behaviours associated with malignant social psychology (restrictive practices or behaviour which objectifies a person), increases in personalised sensory stimulation, gentleness, use of communication that focuses on an individual's feelings, and behaviours which support an individual's strengths and their ability to do what they can for themselves. This expands on the outcomes considered by Fossey et al, (2014), who only list changes to PCC behaviours relating to drug prescribing, gentleness, caregiver bathing behaviour, verbal support, and changes on the care effectiveness scale. It also adds to the outcomes considered by Bird et al., (2016), who reviewed the impact on PCC interventions on changes in "intimate care interactions" (p. 17), summarised as interventions that can improve staff communication, make interactions with people with dementia more humane, and improve staff 
responsiveness. The current review therefore provides additional insights into how staff behaviour towards people with dementia changes following the implementation of a PCC intervention and has started to group these changes in behaviour together in relation to the PCC literature (Kitwood, 1997 \& Edvardsson et al., 2008).

The findings of this review have particular implications for nursing staff implementing PCC interventions. For instance, although the impact of different intervention characteristics could not be formally assessed through a moderation analysis, it was observed that common factor across the interventions with supporting evidence was the provision of more than one episode of staff training. They also often had multiple features involving continued staff support and supervision, action planning across the care setting and organisation, local champions to support front line staff, and opportunities for staff to receive ongoing feedback. This highlights the need for adequate time and resources to be allocated to services when trying to increase PCC.

A particular strength of this review is that a broad and inclusive approach to the concept of PCC was used to search databases. This means that interventions that targeted key features of PCC, but may not have been explicitly labelled as such, were less likely to have been missed from the search. Limitations of this review were that it did not search the grey literature or include studies written in other languages, meaning that some PCC interventions may not have been identified. In addition, only searching peer-reviewed articles may mean that the evidence for effectiveness of PCC interventions is likely to be over-represented (Boland, Cherry \& Dickson, 2014). Another limitation is that, in many cases, the review team were required to make judgements about whether or not an intervention could be considered PCC. However, the liberal approach taken when making these judgments would have minimised the risk of relevant studies being missed.

\section{CONCLUSION}

This review has revealed a diverse range of PCC interventions, and found some evidence to support their effectiveness. However, a lack of strong quality evidence prevented more confident conclusions from being reached about which interventions are most effective. Further high quality studies of PCC interventions, which use RCT designs, are clear about the 
blinding of outcome assessors, and use standardised measures of staff PCC behaviour to assess the impact of the intervention on staff PCC behaviour, are required. 


\section{REFERENCES}

Allen-Burge, R., Burgio, L. D., Bourgeois, M. S., Sims, R., \& Nunnikhoven, J. (2001). Increasing communication among nursing home residents. Journal of Clinical Geropsychology, 7(3), 213-230. doi:http://dx.doi.org/10.1023/A:1011343212424

Alzheimer's Society (2013). Low expectations: Attitudes on choice, care, and community for people with dementia in care homes. Retrieved from https://www.alzheimers.org.uk/download/downloads/id/1628/alzheimers society low expectations report.pdf.

Azheimer's Society. (2014a). Dementia UK: second edition. London: Alzheimer's Society. Retrieved from https://s3.amazonaws.com/14078 Alzheimers Interactive Infographic/pdf/as downlo adable infographics.pdf

Alzheimer's Society. (2014). Dementia 2014: opportunity for change. Retrieved from https://www.alzheimers.org.uk/download/downloads/id/2317/dementia 2014 opport unity for change.pdf

Barbosa, A., Marques, A., Sousa, L., Nolan, M., \& Figueiredo, D. (2016). Effects of a psychoeducational intervention on direct care workers' communicative behaviors with residents with dementia. Health Communication, 31(4), 453-459. doi:http://dx.doi.org/10.1080/10410236.2014.965382

Barbosa, A., Nolan, M., Sousa, L., Marques, A., \& Figueiredo, D. (2016). Effects of a Psychoeducational Intervention for Direct Care Workers Caring for People With Dementia: Results From a 6-Month Follow-Up Study. American Journal of Alzheimer's Disease \& Other Dementias, 31(2), 144-155. doi:http://dx.doi.org/10.1177/1533317515603500

Barbosa, A., Sousa, L., Nolan, M., \& Figueiredo, D. (2015). Effects of person-centered care approaches to dementia care on staff: A systematic review. American Journal of 
Alzheimer's Disease and Other Dementias, 30(8), 713-722.

doi:http://dx.doi.org/10.1177/1533317513520213

Boland, A., Cherry, M. G., \& Dickson, R. (Eds.). (2014). Doing a systematic review: a student's guide. London: Sage.

Bird, M., Anderson, K., MacPherson, S., \& Blair, A. (2016). Do interventions with staff in long-term residential facilities improve quality of care or quality for life people with dementia? A systematic review of the evidence. International Psychogeriatrics, 1-27. doi:http://dx.doi.org/10.1017/S1041610216001083

Boettcher, I. F., Kemeny, B., DeShon, R. P., \& Stevens, A. B. (2004). A system to develop staff behaviors for person-centered care. Alzheimer's Care Quarterly, 5(3), 188-196.

Boland, A., Cherry, M. G., \& Dickson, R. (Eds.). (2014). Doing a systematic review: a student's guide. London: Sage.

Boscart, V. M. (2009). A communication intervention for nursing staff in chronic care. Journal of Advanced Nursing, 65(9), 1823-1832. doi:10.1111/j.1365-2648.2009.05035.x

Bourgeois, M. S., Dijkstra, K., Burgio, L. D., \& Allen, R. S. (2003). Communication skills training for nursing aides of residents with dementia: The impact of measuring performance. Clinical Gerontologist: The Journal of Aging and Mental Health, 27(1-2), 119-138. doi:http://dx.doi.org/10.1300/J018v27n01 10

Brooker, D. (2004). What is person-centred care in dementia? Reviews in Clinical Gerontology, 13, 215-222. doi: 10.1017/S095925980400108X

Brooker, D., Foster, N., Banner, A., Payne, M., \& Jackson, L. (1998). The efficacy of Dementia Care Mapping as an audit tool: Report of a 3-year British NHS evaluation. Aging \& Mental Health, 2(1), 60-70. doi:http://dx.doi.org/10.1080/13607869856957 
Brooker, D. (2003). What is person-centred care in dementia? Reviews in Clinical Gerontology, 13, 215-222. doi:10.1017/S095925980400108X

Brooker, D. J., Woolley, R. J., \& Lee, D. (2007). Enriching opportunities for people living with dementia in nursing homes: An evaluation of a multi-level activity-based model of care. Aging \& Mental Health, 11(4), 361-370. doi:10.1080/13607860600963679

Brooker, D. \& Woolley, R. J. (2007). Enriching opportunities for people living with dementia: The development of a blueprint for a sustainable activity-based model. Aging \& Mental Health, 11(4), 371-383. doi: 10.1080/13607860600963687

Burgio, L. D., Allen-Burge, R., Roth, D. L., Bourgeois, M. S., Dijkstra, K., Gerstle, J. ... Bankester, L. (2001). Come talk with me: Improving communication between nursing assistants and nursing home residents during care routines. The Gerontologist, 41(4), 449-460. doi:http://dx.doi.org/10.1093/geront/41.4.449

Burgio, L. D., Stevens, A., Burgio, K. L., Roth, D. L., Paul, P., \& Gerstle, J. (2002). Teaching and maintaining behavior management skills in the nursing home. Gerontologist, 42(4), 487-496.

Chao, H. C., Kaas, M., Su, Y. H., Lin, M. F., Huang, M. C., \& Wang, J. J. (2016). Effects of the Advanced Innovative Internet-Based Communication Education Program on Promoting Communication Between Nurses and Patients With Dementia. Journal of Nursing Research, 24(2), 163-172. doi:10.1097/jnr.0000000000000109

Chenoweth, L., \& Jeon, Y.-H. (2007). Determining the efficacy of dementia care mapping as an outcome measure and a process for change: A pilot study. Aging \& Mental Health, 11(3), 237-245. doi:http://dx.doi.org/10.1080/13607860600844226

Cooke, H. A., \& Chaudhury, H. (2013). An examination of the psychometric properties and efficacy of Dementia Care Mapping. Dementia, 12(6), 790-805. 
Dean, R., Proudfoot, R., \& Lindesay, J. (1993). The Quality of Interactions Schedule (QUIS):

Development, reliability and use in the evaluation of two domus units.

International Journal of Geriatric Psychiatry, 8(10), 819-826.

Department of Health. (2001). National Service Framework for Older People. Retrieved from:

https://assets.publishing.service.gov.uk/government/uploads/system/uploads/att achment_data/file/198033/National_Service_Framework_for_Older_People.pdf

Department of Health. (2009). Living well with dementia: A National Dementia Strategy. Retrieved from

https://www.gov.uk/government/uploads/system/uploads/attachment data/file/ $\underline{168220 / \mathrm{dh} 094051 . \mathrm{pdf}}$

Department of Health. (2013). Dementia: A state of the nation report on dementia care and support in England. Retrieved from:

http://www.rjah.nhs.uk/RJAHNHS/files/38/38348cef-4088-4f43-b417b06952c02327.pdf

Department of Health. (2015). Prime Minister's challenge on dementia 2020. Retrieved from https://www.gov.uk/government/publications/prime-ministers-challenge-ondementia-2020

de Silva, D. (2014). Helping measure person-centred care: A review of evidence about commonly used approaches and tools used to help measure person-centred care. The Health Foundation Inspiring Improvement. Retrieved from: https://www.health.org.uk/sites/default/files/HelpingMeasurePersonCentredCare.p df

Dijkstra, K., Bourgeois, M., Burgio, L., \& Allen, R. (2002). Effects of a communication intervention on the discourse of nursing home residents with dementia and their nursing assistants. Journal of Medical Speech-Language Pathology, 10(2), 143-157. 
Edberg, A., Hallberg, I. R., \& Gustafson, L. (1996). Effects of clinical supervision on nursepatient cooperation quality: a controlled study in dementia care including commentary by Iwasiw CL and Bol N. Clinical Nursing Research, 5(2), 127-149.

Edvardsson, D., Sandman, P., \& Borell, L. (2014). Implementing national guidelines for person-centered care of people with dementia in residential aged care: Effects on perceived person-centeredness, staff strain, and stress of conscience. International Psychogeriatrics, 26(7), 1171-1179.

doi:http://dx.doi.org/10.1017/S1041610214000258

Edvardsson, D., Winbald, B., \& Sandman, P, O. (2008). Person-centred care of people with severe Alzheimer's disease: current status and ways forward. The Lancet Neurology, 7, 362-367.

Erikson, E. H. (1982). The Life Cycle Completed. New York, NY: W. W. Norton and Co

Fossey, J., Masson, S., Stafford, J., Lawrence, V., Corbett, A., \& Ballard, C. (2014). The disconnect between evidence and practice: A systematic review of person-centred interventions and training manuals for care home staff working with people with dementia. International Journal of Geriatric Psychiatry, 29(8), 797-807. doi:http://dx.doi.org/10.1002/gps.4072

Fritsch, T., Kwak, J., Grant, S., Lang, J., Montgomery, R. R., \& Basting, A. D. (2009). Impact of TimeSlips, a creative expression intervention program, on nursing home residents with dementia and their caregivers. The Gerontologist, 49(1), 117-127. doi:http://dx.doi.org/10.1093/geront/gnp008

Galik, E., Resnick, B., Hammersla, M., \& Brightwater, J. (2013). Optimizing function and physical activity among nursing home residents with dementia: testing the impact of function-focused care. The Gerontologist, 54(6), 930-943. doi:http://dx.doi.org/10.1093/geront/gnt108 
Galik, E., Resnick, B., Lerner, N., Hammersla, M., \& Gruber-Baldini, A. L. (2015). Function Focused Care for Assisted Living Residents With Dementia. Gerontologist, 55 Suppl 1, S13-26. doi:http://dx.doi.org/10.1093/geront/gnu173

Hoeffer, B., Talerico, K. A., Rasin, J., Mitchell, C., Stewart, B. J., McKenzie, D., ... Sloane, P. D. (2006). Assisting Cognitively Impaired Nursing Home Residents With Bathing: Effects of Two Bathing Interventions on Caregiving. The Gerontologist, 46(4), 524532. doi:http://dx.doi.org/10.1093/geront/46.4.524

Hoerster, L., Hickey, E. M., \& Bourgeois, M. S. (2001). Effects of memory aids on conversations between nursing home residents with dementia and nursing assistants. Neuropsychological Rehabilitation, 11(3-4), 399-427. doi:http://dx.doi.org/10.1080/09602010042000051

Jeon, Y.-H., Luscombe, G., Chenoweth, L., Stein-Parbury, J., Brodaty, H., King, M., \& Haas, M. (2012). Staff outcomes from the Caring for Aged Dementia Care REsident Study (CADRES): A cluster randomised trial. International Journal of Nursing Studies, 49(5), 508-518. doi:http://dx.doi.org/10.1016/i.ijnurstu.2011.10.020

Kihlgren, M., Hallgren, A., Norberg, A., Brane, G., \& Karlsson, I. (1990). Effects of the training of integrity--promoting care on the interaction at a long-term ward. Analysis of video-recorded social activities. Scandinavian Journal of Caring Sciences, 4(1), 2128.

Kihlgren, M., Kuremyr, D., Norberg, A., Brane, G., Karlson, I., Engstrom, B., \& Melin, E. (1993). Nurse-patient interaction after training in integrity promoting care at a long-term ward: analysis of video-recorded morning care sessions. International Journal of Nursing Studies, 30(1), 1-13.

Kitwood, T., M. (1997). Dementia Reconsidered: the person comes first Maidenhead: Open University Press. 
Livingston, G., Lewis-Holmes, E., Kelly, L., Baio, G., Morris, S., Patel, N., ... Cooper, C. (2014). Non-pharmacological interventions for agitation in dementia: systematic review of randomised controlled trials. The British Journal of Psychiatry, 205, 436-442. doi:10.1192/bjp.bp.113.141119

Low, L. F., Fletcher, J, Goodenough, B, Jeon, Y-H, Etherton-Beer, C, MacAndrew, M, \& Beattie, E. (2015). A Systematic Review of Interventions to Change Staff Care Practices in Order to Improve Resident Outcomes in Nursing Homes. PLOS ONE, 10(11), 1-60. doi:10.1371/journal.pone.0140711

Martin, G., \& Younger, D. (2001). Person-centred care for people with dementia: A quality audit approach. Journal of Psychiatric and Mental Health Nursing, 8(5), 443-448. doi:http://dx.doi.org/10.1046/i.1351-0126.2001.00427.x

Meyer, J. (2000). Using qualitative methods in health related action research. Bmj, 320, 178181.

Mother, D., Liberati, A., Tetzlaff, J., \& Altman, D. (2009). Preferred reporting items for systematic reviews and meta-analyses: the PRISMA statement. PLoS Med, 6(7), e1000097.

NHS. (2017). Next steps on the NHS five year forward view. Retrieved from https://www.england.nhs.uk/wp-content/uploads/2017/03/NEXT-STEPS-ON-THENHS-FIVE-YEAR-FORWARD-VIEW.pdf

NICE (2006). Dementia: supporting people with dementia and their carers in health and social care. Retrieved from https://www.nice.org.uk/guidance/cg42

Passalacqua, S. A., \& Harwood, J. (2012). VIPS communication skills training for paraprofessional dementia caregivers: An intervention to increase person-centered 
dementia care. Clinical Gerontologist: The Journal of Aging and Mental Health, 35(5), 425-445. doi:http://dx.doi.org/10.1080/07317115.2012.702655

Puffer, S., Torgerson, D, J., \& Watson, J. (2003). Evidence for risk of bias in cluster randomised trials: review of recent trials published in three general medical journals. Bmj, 327, 785-789.

Royal College of Nursing. (2010). Policy briefing 04/2010: Care homes under pressure - an England report. Retrieved from https://www2.rcn.org.uk/ data/assets/pdf file/0006/314547/Policy ReportCare Homes under pressure final web.pdf

Royal College of psychiatrists (2018). Person centred care: implications for training in psychiatry. Retrieved from https://www.rcpsych.ac.uk/docs/default-source/improving-care/better-mhpolicy/college-reports/college-report-cr215.pdf?sfvrsn=7863b905_2

Sidani, S., LeClerc, C., \& Streiner, D. (2009). Implementation of the abilities-focused approach to morning care of people with dementia by nursing staff. International Journal of Older People Nursing, 4(1), 48-56. doi:http://dx.doi.org/10.1111/j.1748$\underline{3743.2008 .00154 . x}$

Sidani, S., Streiner, D., \& LeClerc, C. (2011). Evaluating the effectiveness of the abilitiesfocused approach to morning care of people with dementia. International Journal of Older People Nursing, 7, 37-45. doi: 10.1111/j.1748-3743.2011.00273.x

Sohn, W., Ismail, A. I., \& Tellez, M. (2004). Efficacy of Educational Interventions Targeting Primary Care Providers' Practice Behaviors: an Overview of Published Systematic Reviews. Jounral of Public Health Denistry, 64(3), 164- 172.

Sprangers, S., Dijkstra, K., \& Romijn-Luijten, A. (2015). Communication skills training in a nursing home: Effects of a brief intervention on residents and nursing aides. 
Clinical Interventions in Aging, 10, 311-319.

doi:http://dx.doi.org/10.2147/CIA.S73053

Thomas, b. H., Ciliska, D., Dobbins, M., \& Micucci, S. (2004). A process for Systematically Reviewing the literature: Providing the Research Evidence for Public Health Nursing Interventions. Worldviews on Evidence-Based Nursing, 1(3), 176-184.

van der Kooij, C., Droes, R., de Lange, J., Ettema, T., Cools, H., \& van Tilburg, W. (2012). The implementation of integrated emotion-oriented care: Did it actually change the attitude, skills and time spent of trained caregivers? Dementia: The International Journal of Social Research and Practice, 12(5), 536-550.

doi:http://dx.doi.org/10.1177/1471301211435187

van Weert, J. C., van Dulmen, A. M., Spreeuwenberg, P. M., Bensing, J. M., \& Ribbe, M. W. (2005). The effects of the implementation of snoezelen on the quality of working life in psychogeriatric care. International Psychogeriatrics, 17(3), 407-427. doi:http://dx.doi.org/10.1017/S1041610205002176

Van Weert, J. C. M., Janssen, B. M., van Dulmen, A. M., Spreeuwenberg, P. M. M., Bensing, J. M., \& Ribbe, M. W. (2006). Nursing assistants' behaviour during morning care: effects of the implementation of snoezelen, integrated in 24-hour dementia care. Journal of Advanced Nursing, 53(6), 656-668.

Vasse, E., Vernooij-Dassen, M., Spijker, A., Rikkert, M. O., \& Koopmans, R. (2010). A systematic review of communication strategies for people with dementia in residential and nursing homes. International Psychogeriatrics, 22(2), 189-200. doi:http://dx.doi.org/10.1017/S1041610209990615

Weitzel, T., Robinson, S., Mercer, S., Berry, T., Barnes, N., Plunkett, D., Vollmer, C., Foster, T., Friedrich, L., Allen, L., Holmes, J., \& Kirkbride, G. (2011). Pilot Testing an Educational Intervention to Improve Communication With Patients With Dementia. Journal for Nurses in Staff Development, 27(5), 220-226. doi:10.1097/NND.0b013e31822e0738 
Wells, D. L., Dawson, P., Sidani, S., Craig, D., \& Pringle, D. (2000). Effects of an abilitiesfocused program of morning care on residents who have dementia and on caregivers. Journal of the American Geriatrics Society, 48(4), 442-449.

World Health Organization. (2016). Dementia. Retrieved from http://www.who.int/mediacentre/factsheets/fs362/en/ 
Supplementary Table 1. Ovid Search strategy

\begin{tabular}{|c|c|}
\hline Concept & Terms \\
\hline Person-Centred Care & $\begin{array}{l}\text { 'person cent* or patient cent* or } \\
\text { relationship cent* or personhood or positive } \\
\text { person work or malignant social psychology } \\
\text { or unconditional positive regard or } \\
\text { (authentic and (consciousness or contact or } \\
\text { communication)) or shared decision making } \\
\text { or (personalis* or personaliz*) and (environ* } \\
\text { or surround* or care)) or quality of care or } \\
\text { skilled companionship or ((prioritis* or } \\
\text { prioritiz*) and relationship*) or ((prioritis* or } \\
\text { prioritiz*) and well being) or biographical } \\
\text { knowledge or reminiscence or dementia } \\
\text { care mapping or validation therapy or } \\
\text { communication skills or abilit* focus* or } \\
\text { memory aids or integrity promoting or } \\
\text { promot* integrity' }\end{array}$ \\
\hline Intervention & $\begin{array}{l}\text { 'intervention or program or programme or } \\
\text { training or audit or evaluat* or educat*' }\end{array}$ \\
\hline Participants & $\begin{array}{l}\text { 'staff or health care professional or nurs* or } \\
\text { nursing assistants or care assistants or care } \\
\text { workers or caregivers' }\end{array}$ \\
\hline Clinical population & $\begin{array}{l}\text { 'dementia or alzheimer* or cognitive } \\
\text { impairment' }\end{array}$ \\
\hline
\end{tabular}


Supplementary Table 2. Summary of quality review ratings using EPHPP tool

\begin{tabular}{|c|c|c|c|c|c|c|c|}
\hline Study & Selection bias & Design & Confounders & Blinding & $\begin{array}{l}\text { Data } \\
\text { collection }\end{array}$ & $\begin{array}{l}\text { Withdrawals/drop } \\
\text { outs }\end{array}$ & $\begin{array}{l}\text { Overall } \\
\text { rating }\end{array}$ \\
\hline \multicolumn{8}{|c|}{ Staff communication training/Memory book interventions } \\
\hline Boscart (2009) & weak & moderate & weak & moderate & weak & strong & weak \\
\hline Burgio et al., (2001) & moderate & strong & strong & moderate & strong & moderate & strong \\
\hline Burgio et al., (2002) & moderate & strong & strong & moderate & weak & strong & moderate \\
\hline Chao et al., (2016) & weak & moderate & weak & moderate & strong & weak & weak \\
\hline $\begin{array}{l}\text { Passacquala \& } \\
\text { Harwood (2009) }\end{array}$ & moderate & moderate & weak & moderate & weak & strong & weak \\
\hline $\begin{array}{l}\text { Sprangers et al., } \\
\text { (2015) }\end{array}$ & moderate & strong & strong & moderate & strong & strong & strong \\
\hline Weitzel et al., (2011) & moderate & moderate & weak & moderate & weak & strong & weak \\
\hline
\end{tabular}




\begin{tabular}{|c|c|c|c|c|c|c|c|}
\hline \multicolumn{8}{|c|}{ Supporting staff with emotional reactions } \\
\hline $\begin{array}{l}\text { Barbosa et al., (2016) } \\
\text { Barbosa et al., (2016) }\end{array}$ & $\begin{array}{l}\text { moderate } \\
\text { moderate }\end{array}$ & $\begin{array}{l}\text { strong } \\
\text { strong }\end{array}$ & $\begin{array}{l}\text { strong } \\
\text { strong }\end{array}$ & $\begin{array}{l}\text { weak } \\
\text { weak }\end{array}$ & $\begin{array}{l}\text { weak- } \\
\text { strong }\end{array}$ & $\begin{array}{l}\text { strong } \\
\text { strong }\end{array}$ & $\begin{array}{l}\text { weak } \\
\text { moderate }\end{array}$ \\
\hline \multicolumn{8}{|l|}{ DCM } \\
\hline $\begin{array}{l}\text { Chenoweth \& Jeon } \\
\text { (2007) }\end{array}$ & moderate & moderate & weak & moderate & strong & strong & moderate \\
\hline $\begin{array}{l}\text { Jeon et al., (2012) } \\
\text { Martin \& Younger } \\
\text { (2001) }\end{array}$ & $\begin{array}{l}\text { weak } \\
\text { moderate }\end{array}$ & $\begin{array}{l}\text { strong } \\
\text { Weak }\end{array}$ & $\begin{array}{l}\text { weak } \\
\text { weak }\end{array}$ & $\begin{array}{l}\text { moderate } \\
\text { weak }\end{array}$ & $\begin{array}{l}\text { strong } \\
\text { strong }\end{array}$ & $\begin{array}{l}\text { moderate } \\
\text { weak }\end{array}$ & $\begin{array}{l}\text { weak } \\
\text { weak }\end{array}$ \\
\hline \multicolumn{8}{|c|}{ Interventions focused on retaining abilities } \\
\hline $\begin{array}{l}\text { Galik et al., (2013) } \\
\text { Galik et al., (2015) }\end{array}$ & $\begin{array}{l}\text { moderate } \\
\text { moderate }\end{array}$ & $\begin{array}{l}\text { strong } \\
\text { strong }\end{array}$ & $\begin{array}{l}\text { strong } \\
\text { strong }\end{array}$ & $\begin{array}{l}\text { moderate } \\
\text { weak }\end{array}$ & $\begin{array}{l}\text { strong } \\
\text { strong }\end{array}$ & $\begin{array}{l}\text { weak } \\
\text { moderate }\end{array}$ & $\begin{array}{l}\text { moderate } \\
\text { moderate }\end{array}$ \\
\hline Sidani et al., (2009) & moderate & moderate & strong & weak & moderate & weak & weak \\
\hline Sidani et al., (2012) & moderate & moderate & weak & moderate & strong & moderate & moderate \\
\hline Wells et al., (2000) & moderate & strong & weak & moderate & strong & moderate & moderate \\
\hline
\end{tabular}




\begin{tabular}{|c|c|c|c|c|c|c|c|}
\hline $\begin{array}{l}\text { Van Weert et al., } \\
(2005)\end{array}$ & moderate & strong & strong & moderate & strong & weak & moderate \\
\hline $\begin{array}{l}\text { Van Weert et al., } \\
(2006)\end{array}$ & moderate & strong & strong & moderate & weak & weak & weak \\
\hline Fritsch et al., (2009) & weak & strong & strong & moderate & weak & not applicable & weak \\
\hline \multicolumn{8}{|c|}{ Integrity promoting care } \\
\hline Kihlgren et al., (1990) & moderate & strong & weak & moderate & weak & weak & weak \\
\hline Kihlgren et al., (1993) & moderate & strong & weak & moderate & weak & weak & weak \\
\hline \multicolumn{8}{|l|}{ Systemic interventions } \\
\hline $\begin{array}{l}\text { Edvardsson et al., } \\
\text { (2014) }\end{array}$ & moderate & moderate & weak & moderate & strong & strong & moderate \\
\hline $\begin{array}{l}\text { Brooker et al., } \\
\text { (2007) }\end{array}$ & moderate & moderate & weak & moderate & strong & moderate & moderate \\
\hline \multicolumn{8}{|l|}{ Other } \\
\hline $\begin{array}{l}\text { Boettcher et al., } \\
(2004)\end{array}$ & moderate & moderate & weak & moderate & weak & weak & weak \\
\hline Hoeffer et al., (2006) & moderate & strong & weak & moderate & strong & moderate & moderate \\
\hline $\begin{array}{l}\text { van der Kooij et al., } \\
\text { (2012) }\end{array}$ & moderate & Strong & strong & weak & strong & moderate & moderate \\
\hline
\end{tabular}


